OPEN ACCESS

Edited by:

Greg Dussor,

University of Texas at Dallas, United States

Reviewed by: Liang-Wu Fu,

University of California, Irvine, United States Stefania Ceruti,

Università degli Studi di Milano, Italy

${ }^{*}$ Correspondence:

Michael P. Jankowski michael.jankowski@cchmc.org

Received: 20 October 2017 Accepted: 13 December 2017 Published: 22 December 2017

Citation:

Queme LF, Ross JL and Jankowski MP (2017) Peripheral Mechanisms of Ischemic Myalgia.

Front. Cell. Neurosci. 11:419. doi: 10.3389/fncel.2017.00419

\section{Peripheral Mechanisms of Ischemic Myalgia}

\author{
Luis F. Queme ${ }^{1}$, Jessica L. Ross ${ }^{1}$ and Michael P. Jankowski ${ }^{1,2 *}$ \\ 'Department of Anesthesia, Division of Pain Management, Cincinnati Children's Hospital Medical Center, Cincinnati, OH, \\ United States, ${ }^{2}$ Department of Pediatrics, University of Cincinnati College of Medicine, Cincinnati, OH, United States
}

Musculoskeletal pain due to ischemia is present in a variety of clinical conditions including peripheral vascular disease (PVD), sickle cell disease (SCD), complex regional pain syndrome (CRPS), and even fibromyalgia (FM). The clinical features associated with deep tissue ischemia are unique because although the subjective description of pain is common to other forms of myalgia, patients with ischemic muscle pain often respond poorly to conventional analgesic therapies. Moreover, these patients also display increased cardiovascular responses to muscle contraction, which often leads to exercise intolerance or exacerbation of underlying cardiovascular conditions. This suggests that the mechanisms of myalgia development and the role of altered cardiovascular function under conditions of ischemia may be distinct compared to other injuries/diseases of the muscles. It is widely accepted that group III and IV muscle afferents play an important role in the development of pain due to ischemia. These same muscle afferents also form the sensory component of the exercise pressor reflex (EPR), which is the increase in heart rate and blood pressure (BP) experienced after muscle contraction. Studies suggest that afferent sensitization after ischemia depends on interactions between purinergic (P2X and P2Y) receptors, transient receptor potential (TRP) channels, and acid sensing ion channels (ASICs) in individual populations of peripheral sensory neurons. Specific alterations in primary afferent function through these receptor mechanisms correlate with increased pain related behaviors and altered EPRs. Recent evidence suggests that factors within the muscles during ischemic conditions including upregulation of growth factors and cytokines, and microvascular changes may be linked to the overexpression of these different receptor molecules in the dorsal root ganglia (DRG) that in turn modulate pain and sympathetic reflexes. In this review article, we will discuss the peripheral mechanisms involved in the development of ischemic myalgia and the role that primary sensory neurons play in EPR modulation.

Keywords: muscle pain, ischemia, dorsal root ganglion, primary afferents, exercise pressor reflex

\section{INTRODUCTION}

Pain is a common clinical complaint resulting in a significant financial burden to both patients and society. In the U.S. alone, studies have estimated the mean cost of pain per patient at about $\$ 9 \mathrm{~K}$ in adults and $\$ 12 \mathrm{~K}$ in adolescents. The annual cost to society is over $\$ 635$ billion (Gaskin and Richard, 2012; Groenewald et al., 2014). Because chronic muscle pain is a major cause of disability and lost productivity within the workforce (Bergman et al., 2001; Mansfield et al., 2016), the societal burden of myalgia significantly exceeds the basic expenses 
of pain treatment (Gaskin and Richard, 2012). Furthermore, due to the frequent underreporting and often nebulous etiology of muscle pain conditions, precise epidemiological analyses of the chronic myalgia burden are rare (Mansfield et al., 2016).

Assessment of musculoskeletal pain is also complicated by its characteristics. Unlike the typically localized pain that arises from insults to the skin, myalgia is often diffuse and more likely to evoke referred pain (Bonica, 1954; Mense and Simons, 2001; Graven-Nielsen et al., 2004). Terms used to describe sensations of deep tissue pain, such as "cramping", "aching" and "tearing", vary widely between patients and over time, whereas cutaneous pain tends to have a more consistent presentation often described as having a "burning" or "cutting" quality (Mense, 2008). Additionally, physicians have a particular challenge in determining appropriate pain management strategies for myalgia in that a treatment's therapeutic efficacy is often etiologydependent (Mense, 2008; Clauw, 2015). In the management of persistent muscle pain, first-line therapies often consist of opioids, non-steroidal anti-inflammatory drugs (NSAIDs), and physical activity regimens (Light et al., 2009; Ambrose and Golightly, 2015; Clauw, 2015; Bacurau et al., 2016); however, these types of interventions may be ineffective or even detrimental in some patient populations (Kindler et al., 2011; Murphy et al., 2011; Clauw, 2015). Thus, understanding how muscle pain arises across various diseases and injury types is paramount for increasing the availability and efficacy of specific pain management strategies.

People of all ages and demographics can be affected by muscle pain. The prevalence of the various underlying causes is known to differ between patient groups (Bergman et al., 2001; De Inocencio, 2004; Clauw, 2015; Mansfield et al., 2016). While the most frequent source of myalgia across ages is either overuse or traumatic injury (De Inocencio, 2004), there is a diversity of etiologies that include strenuous work and muscle overloading (Andersen and Gaardboe, 1993; Buckwalter, 2003), quick deceleration injuries like whiplash (Banic et al., 2004; Curatolo et al., 2004), joint diseases with peripheral inflammation (Graven-Nielsen and Mense, 2001; Kidd, 2006; Bliddal and Danneskiold-Samsoe, 2007) and ischemic injury (McDermott et al., 2004; Coderre and Bennett, 2010; Davies, 2012). This latter condition is of particular relevance because not only does it affect over 10 million people in the US alone (Norgren et al., 2007), patients often do not respond to many standard analgesic regimens for muscle pain relief (Loram et al., 2005; Clauw, 2015).

Numerous basic and clinical reports have shown that ischemic conditions are able to generate muscle pain (Alam and Smirk, 1937; Sinoway et al., 1989; Coderre et al., 2004; Laferrière et al., 2008; Ross et al., 2014). Decreased blood flow to the skeletal muscle that impairs oxygen supply sufficient to inadequately meet the metabolic demands of the tissue is a feature of multiple clinical conditions in which patients often report deep tissue pain (Dennis and Keating, 1991; Norris et al., 1993; Kasikcioglu et al., 2006; Katz et al., 2007; Nishida et al., 2009; Coderre and Bennett, 2010; McDermott, 2015). In this context, age is an important epidemiological variable. In pediatric patients, ischemic pain is often the result of pathologies like sickle cell disease (SCD), juvenile fibromyalgia (JFM) and complex regional pain syndrome (CRPS; Groeneweg et al., 2009; Zemel and Blier, 2016; Bou-Maroun et al., 2018). In adults, peripheral vascular disease (PVD) is a more prevalent cause of ischemic myalgia (McDermott et al., 2004; Norgren et al., 2007; Muir, 2009).

The origin of the muscle pain is evident in cases like PVD, where there is a mechanical obstruction of the vasculature due to atherosclerosis for example, or in SCD, in which the sickling crises induce both mechanical obstructions and hemolytic anemia (Hands et al., 1990; Beard, 2000; Meru et al., 2006; Davies, 2012; Garrison et al., 2012; Brandow et al., 2013). In other cases, anomalies in peripheral perfusion have also been hypothesized to be major contributors to the painful symptoms of conditions like CRPS and fibromyalgia (FM; Elvin et al., 2006; Coderre and Bennett, 2010; Chalaye et al., 2014). In the case of type 1 CRPS, it has been proposed that the perfusion anomalies are the consequence of a hyperactive sympathetic outflow (Bonica, 1990; Iolascon et al., 2015), usually in response to a deep tissue injury in which inflammation causes a compartment-like syndrome that impairs perfusion to the affected tissues (Coderre and Bennett, 2010). In FM, the driving factors that lead to the development of deep tissue pain are less clear, yet, studies in patients have shown impaired perfusion within the painful areas of the body (Jeschonneck et al., 2000; Morf et al., 2005; Elvin et al., 2006; McIver et al., 2006). Evidence of this deficit has been detected using enhanced ultrasound imaging of muscular blood flow during static and dynamic contractions. These studies have reported lower muscle vascularity that was accompanied by a shorter flow response to muscle activity in FM patients (Elvin et al., 2006). Furthermore, the microcirculation, measured by laser Doppler flowmetry, above sensitive points in FM patients is reported to be decreased compared to healthy controls (Jeschonneck et al., 2000).

Severe muscle ischemia is most often not permanent. Blood flow is at least partially reestablished and this causes a complex ischemia-reperfusion (I/R) injury that is characterized by the generation of free radicals (Debold, 2015) and reactive oxygen species like hydrogen peroxide (Paradis et al., 2016) that impair mitochondrial function, damage muscle fibers and promote apoptosis (Pipinos et al., 2008a,b; McDermott, 2015; Ryan et al., 2015). In addition, during the reperfusion phase, the muscle microvasculature experiences increased permeability and injury that facilitates the sequestration of activated lymphocytes in the injured tissue. These cells, mostly macrophages and neutrophils, release pro-algesic cytokines like interleukin-1 (IL-1), tumor necrosis factor and many others (Figure 1). Intracellular granules containing radical forming enzymes can further increase cell damage and in turn enhance the immune response to injury (Blaisdell, 2002; Eisenhardt et al., 2012; Gillani et al., 2012). The duration of the insult is also relevant, as the underlying mechanisms of muscle pain generation in disorders of peripheral perfusion seem to depend on the length of ischemia and/or reperfusion; partially due to enhanced muscle atrophy and microvascular changes observed following a prolonged occlusion over those detected following a transient I/R injury (Blaisdell, 2002; Eisenhardt et al., 2012; Ross et al., 2014). 


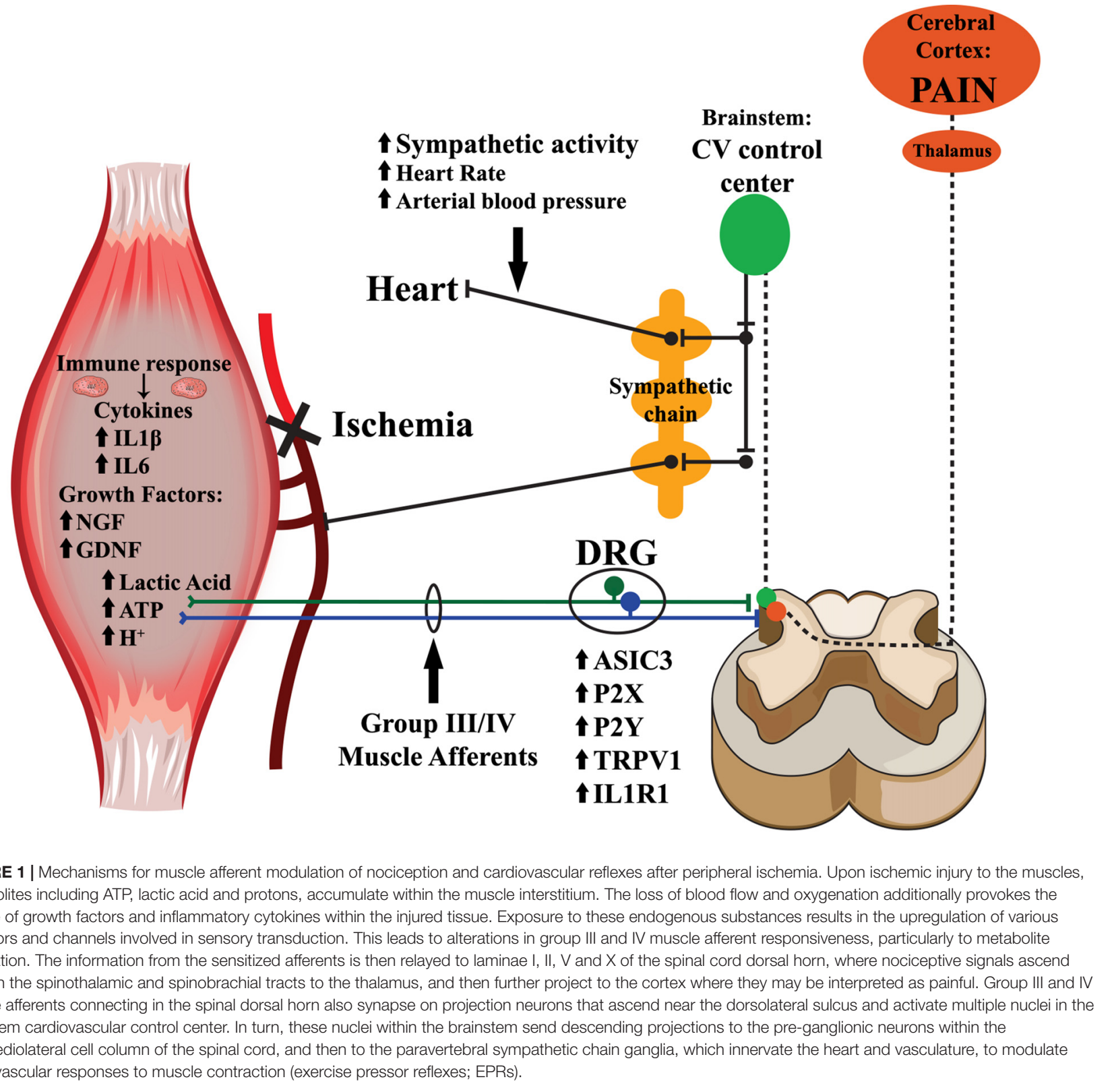

To study the basic mechanisms of post-ischemic pain, a variety of animal models have been developed. One of these, uses circumferential compression of the limb to induce an I/R-like injury (Coderre et al., 2004). Additional types of I/R, as well as prolonged ischemia, have also been modeled via surgical occlusion of a peripheral artery (Lee et al., 2005; Xing et al., 2008; Liu et al., 2010; Tsuchimochi et al., 2010; Li et al., 2014; Ross et al., 2014; Copp et al., 2015; Stone et al., 2015). Furthermore, injury-specific effects on muscle afferent sensitization and responsiveness have been investigated in both ex vivo (Jankowski et al., 2013) and in vitro conditions (Wenk and McCleskey, 2007; Light et al., 2008). These models and methods have provided a wealth of data indicating that the primary sensory afferents are likely key components in the development of ischemic myalgia (Kehl et al., 2000; Taguchi et al., 2005; Sluka et al., 2007; Gautam et al., 2010; Xu and Brennan, 2010; Ross et al., 2014).

Group III and IV primary muscle afferents are not solely involved in nociception; they also provide the peripheral sensory input for the exercise pressor reflex (EPR), a well-studied cardiovascular reflex arc that causes an increase in heart rate and blood pressure (BP) during exercise (Alam and Smirk, 1937; McCloskey and Mitchell, 1972a,b; Randich and Maixner, 1984; Zamir and Maixner, 1986; Adreani and Kaufman, 1998; Kaufman and Hayes, 2002; Hayes et al., 2008; Ives et al., 2013). Ablating these muscle sensory neurons specifically abolishes the EPR in response to muscle contraction (McCloskey and Mitchell, 1972b; Kaufman and Hayes, 2002). Animal models of ischemic injury 
display enhanced muscle pain responses (Issberner et al., 1996; Coderre et al., 2004; Liu et al., 2010; Seo et al., 2010; Xing et al., 2012; Ross et al., 2014), as well as altered EPR (Alam and Smirk, 1937; McCloskey and Mitchell, 1972a,b; Randich and Maixner, 1984; Zamir and Maixner, 1986; Adreani and Kaufman, 1998; Kaufman and Hayes, 2002; Hayes et al., 2008; Ives et al., 2013). This is not surprising as there is a well-documented anatomical pathway of afferent projections both directly engaging the central nociceptive networks in the ipsilateral dorsal horn and indirectly modulating the cardiovascular control centers within the medullary brainstem that influence sympathetic tone and increase systemic BP and heart rate during muscle contractions (Figure 1; Randich and Maixner, 1984; Zamir and Maixner, 1986; Kaufman and Hayes, 2002; Murphy et al., 2011). In addition, patients experiencing ischemic conditions like PVD or CRPS also have exaggerated EPRs (Adreani and Kaufman, 1998; Jänig and Baron, 2003; Li and Xing, 2012; Bartur et al., 2014; Li et al., 2014; Muller et al., 2015; Stone and Kaufman, 2015). This increased cardiovascular response to exercise can promote exercise intolerance and complicate physical therapy as well as increase the susceptibility to further cardiac events (Murphy et al., 2011; Wang et al., 2012; Gibbons et al., 2015; Bacurau et al., 2016), making this a clinically relevant complication of ischemic injury.

In this review article, we will discuss the role of peripheral afferents in sensing ischemic conditions in the periphery and the changes that injuries can induce in the response properties of these neurons. We will also examine how dynamic changes in gene expression modulate afferent responses as a direct consequence of changing external signals that include muscle metabolites, cytokines and growth factors. Finally, we will examine how the same peripheral nociceptors modulate the cardiovascular responses to exercise and how this is a potential mechanism for the development of chronic ischemic myalgia (Figure 1).

\section{ROLE OF PRIMARY MUSCLE AFFERENTS IN DUALLY MODULATING ISCHEMIC MYALGIA AND THE EXERCISE PRESSOR REFLEX}

Painful sensations in the muscle are detected by group III and group IV primary afferents, which are the muscular analog of cutaneous $\mathrm{A} \delta$ and $\mathrm{C}$ fibers. These thinly myelinated (A $\delta$ ) and unmyelinated $(\mathrm{C})$ neurons, whose cell bodies rest in the dorsal root ganglia (DRG), consist primarily of a long axon that gives rise to free nerve endings in the muscle tissue (Stacey, 1969; Messlinger, 1996). Some studies have also associated these free nerve endings with the muscle microvasculature and related their function with detecting specific changes in blood vessel distention (Haouzi et al., 1995, 1999; Reinert et al., 1998). While some of these muscle afferents are anatomically close to the blood vessels in muscle tissue and even express vasodilatory peptides (Molliver et al., 2005), it is known that these afferents innervate different structures in the muscle, including the perimysium, the peritendineum and even the muscle fascia
(Andres et al., 1985; Messlinger, 1996; Mense, 2010; Taguchi et al., 2013). These sensory neurons also respond to a variety of stimuli including mechanical deformation of the muscles, a wide range of temperatures and changes in the intramuscular chemical environment that includes protons, various metabolites (e.g.: lactate, ATP, ADP) or in some cases noxious free radicals like hydrogen peroxide (Mense and Schmidt, 1974; Kumazawa and Mizumura, 1976; Kaufman et al., 1984; Iwamoto et al., 1985; Delliaux et al., 2009; Xu and Brennan, 2009; McCord et al., 2010; Jankowski et al., 2013; Sugiyama et al., 2017a,b).

Initially, group III and IV muscle afferents were studied to determine their roles in the generation of the EPR (McCloskey and Mitchell, 1972a; Iwamoto et al., 1985). Under normal perfusion, muscle contractions may preferentially stimulate group III afferents, but under ischemic conditions, group IV muscle afferents may be preferentially activated (Kaufman et al., 1984). Furthermore, ischemia increases the response to contractions of about $50 \%$ of group IV muscle afferents but only about $12 \%$ of group III afferents. Increased primary afferent responses under ischemia lead to increased EPRs characterized by a specific increase in the mean arterial pressure (MAP; Tsuchimochi et al., 2010). This observation is supported by similar findings in patients suffering from PVD (Baccelli et al., 1999; Li and Xing, 2012; Stone and Kaufman, 2015). The results thus suggest that there are specific subpopulations of group III and IV afferents that are sensitized by ischemia (Kaufman et al., 1984; Stone et al., 2015), and that these neurons can respond to the specific metabolites produced by muscle activity during impaired perfusion. Specifically, ATP (Kindig et al., 2007; McCord et al., 2010; Stone et al., 2014), and low pH, as consequence of increased lactic acid production (Immke and McCleskey, 2001; Molliver et al., 2005; McCord et al., 2009; Tsuchimochi et al., 2011; Pollak et al., 2014), can effectively trigger responses from muscle sensory neurons.

In vitro studies from Light et al. (2008) using calcium imaging on DRG neurons exposed to different concentrations of metabolites solidify this concept. Different concentrations of metabolites: $\mathrm{pH}$ between 7.6 and 6.2 , lactate between $1 \mathrm{mM}$ and $50 \mathrm{mM}$, and ATP from $300 \mathrm{nM}$ to $5 \mu \mathrm{M}$, all replicating values observed in the muscle interstitium during mild to extreme exercise, were used to stimulate cultured DRG neurons. One of the most interesting findings is that if the metabolites were applied alone, very few neurons would be activated. However, lactate and ATP enhanced the responses induced by low $\mathrm{pH}$. ATP at very high concentrations could activate neurons independently, but not at physiological concentrations. This point is supported by behavioral experiments where stimulating the muscles with ATP, lactate or low $\mathrm{pH}$ by themselves are unable to induce painful responses (Gregory et al., 2015). Interestingly the enhanced responses obtained by combining the metabolites in a way that it resembled physiological conditions provided effective neuronal activation that was more than additive in up to $30 \%$ of the observed neurons. Only this combination of ATP, lactate and protons was able to induce mechanical hyperalgesia (Gregory et al., 2015).

Finally, two discrete populations of chemosensitive neurons have been reported by Light et al. (2008). One population of 
neurons can be described as "low metabolite responders" which increases their responses from $\mathrm{pH} 7.4(1 \mathrm{mM}$ lactate and $300 \mathrm{nM}$ ATP) up to pH 7.0 (15 mM lactate and $1 \mu \mathrm{M}$ ATP). A second population of "high metabolite responders" starts responding around $\mathrm{pH} 7.0$ (15 $\mathrm{mM}$ lactate $1 \mu \mathrm{M}$ ATP) and increases in responses up to $\mathrm{pH} 6.6(50 \mathrm{mM}$ lactate and $5 \mu \mathrm{M}$ ATP). These observations suggest that there is one group of primary afferents that senses the chemical environment of the muscles during normal work-related activity (metaboreceptors/"low" metabolite responders), and a separate population that detects concentrations of metabolites that are produced during noxious, ischemic contractions (metabonociceptors/"high" metabolite responders). These sensory neurons may be an important component of the sensory machinery involved in detecting ischemia and ischemic injury in muscle tissue. Studies in human volunteers support this notion. Subjects who received an intramuscular injection of the "low metabolite" mixture, reported a sensation of muscle fatigue. In contrast, when volunteers were injected with the higher concentration mixture of these metabolites, they reported a painful sensation (Pollak et al., 2014).

The different subpopulations of primary muscle afferents which include mechanoreceptors, thermoreceptors, chemoreceptors and their nociceptive variants (metaboreceptors and metabonociceptors), as well as polymodal nociceptors have been extensively characterized electrophysiologically both in vitro and ex vivo (Kaufman et al., 1984; Light et al., 2008; Jankowski et al., 2013; Ross et al., 2014, 2016; Stone et al., 2015; Queme et al., 2016). Single unit recordings using an ex vivo muscle/nerve/DRG/spinal cord preparation, found that about $70 \%$ of group III neurons are mechanically sensitive compared to only about $30 \%$ of group IV afferents. Most of the group IV sensory fibers $(\sim 60 \%)$ were chemosensitive. In line with the work of Light et al. (2008), two discrete populations of neurons were also observed in these studies: one responded to a "low metabolite" mixture (15 mM lactate, $1 \mu \mathrm{M}$ ATP, pH 7.0) and one to a "high metabolite" mixture (50 mM lactate, $5 \mu \mathrm{M}$ ATP, $\mathrm{pH}$ 6.6). These metabolite responsive subtypes correspond to the metaboreceptor ("low" responders) and metabonociceptor ("high" responders) populations. Moreover, the response characteristics of these neurons seem to be mutually exclusive, as very few neurons responded to both combinations of metabolites under naïve/uninjured conditions (Jankowski et al., 2013; Ross et al., 2014, 2016; Queme et al., 2016).

The two previously mentioned sub-populations of metaboreceptors ("low metabolite" responders) and metabonociceptors ("high metabolite" responders) along with their response properties are extensively altered following ischemic injury. Transient or prolonged ischemic insult to the muscles decreased mechanical thresholds and increased firing to mechanical stimulation in group III and IV muscle afferents (Ross et al., 2014, 2016; Queme et al., 2016). The responsiveness to "low metabolites" was also increased after I/R (Ross et al., 2014, 2016). A striking finding of these studies was that after ischemic injury, the number of metaboreceptors in the DRG was decreased compared to un-injured controls. This was concurrent with an increase in afferents responsive to both noxious and non-noxious metabolite stimulation; a population that is not readily detectable under naïve conditions (Ross et al., 2014, 2016; Queme et al., 2016). The appearance of this novel population of chemosensitive muscle afferents suggests a phenotypic switch in the composition of afferents in the DRG after injury.

The increased mechanical sensitivity in primary afferents as well as the enhanced response to "low metabolites", combined with the greater number of afferents responding to both noxious and non-noxious metabolite stimuli, correlate with increased behavioral responses after ischemic injury. In rats, models that cause ischemia-reperfusion via a hind limb tourniquet induced mechanical hyperalgesia and allodynia in the treated animals, accompanied by cold hyperalgesia (Coderre et al., 2004). The animals in this study also showed spontaneous pain-related behaviors and contralateral pain. Moreover, this type of ischemia did not seem to induce significant nerve damage (Coderre et al., 2004), suggesting that the observed changes in behavior are not due to ischemia-induced neuropathy. Experiments using a surgical occlusion of the arterial blood flow to the upper extremities had similar findings. A model of prolonged ischemic injury using an 18-24 h occlusion of the brachial artery (BAO) induced paw guarding behaviors (a surrogate for spontaneous pain), increased mechanical hypersensitivity and decreased grip strength (Ross et al., 2014; Queme et al., 2016). I/R injury presented similar changes to the prolonged ischemic injury model, although injured animals recovered slightly faster than in the BAO model (Ross et al., 2014). In line with other animal models of pain (e.g., inflammation; Cobos et al., 2012; Grace et al., 2014), I/R also induced decreased voluntary activity (Ross et al., 2014, 2016). Altogether, these reports show the importance of primary muscle afferents in dually regulating pain and EPRs after ischemic insults to the periphery.

\section{RECEPTOR MECHANISMS OF MUSCLE SENSORY NEURON SENSITIZATION AFTER ISCHEMIC INJURY}

After ischemic injury to the periphery, a diversity of channels and membrane receptors are upregulated in the DRGs (Figure 2). Many of these receptors have been linked with the sensitization of afferents, leading to the development of pain or modulation of the EPR. For example, the transient receptor potential (TRP) cation channel vanilloid receptor 1 (TRPV1), appears to mediate increased neuronal responses (Xing et al., 2008) and acid evoked thermal hyperalgesia (Kwon et al., 2014) in animals with a femoral artery occlusion (Seo et al., 2008). Other models show significant increases in the expression of P2X3/4/5, ASIC3 and P2Y1, which have also been linked to muscle afferent function, pain manifestation and EPR modulation post ischemia (McCord et al., 2009, 2010; Liu et al., 2010; Seo et al., 2010; Queme et al., 2016; Ross et al., 2016).

TRPV1 has been associated with the development of ischemic pain in different models. Studies in humanized hemoglobin transgenic SCD mice have shown that TRPV1 plays a role in cutaneous afferent sensitization (Hillery et al., 2011). Since SCD-induced vaso-occlusive crises primarily affect deep tissues, 


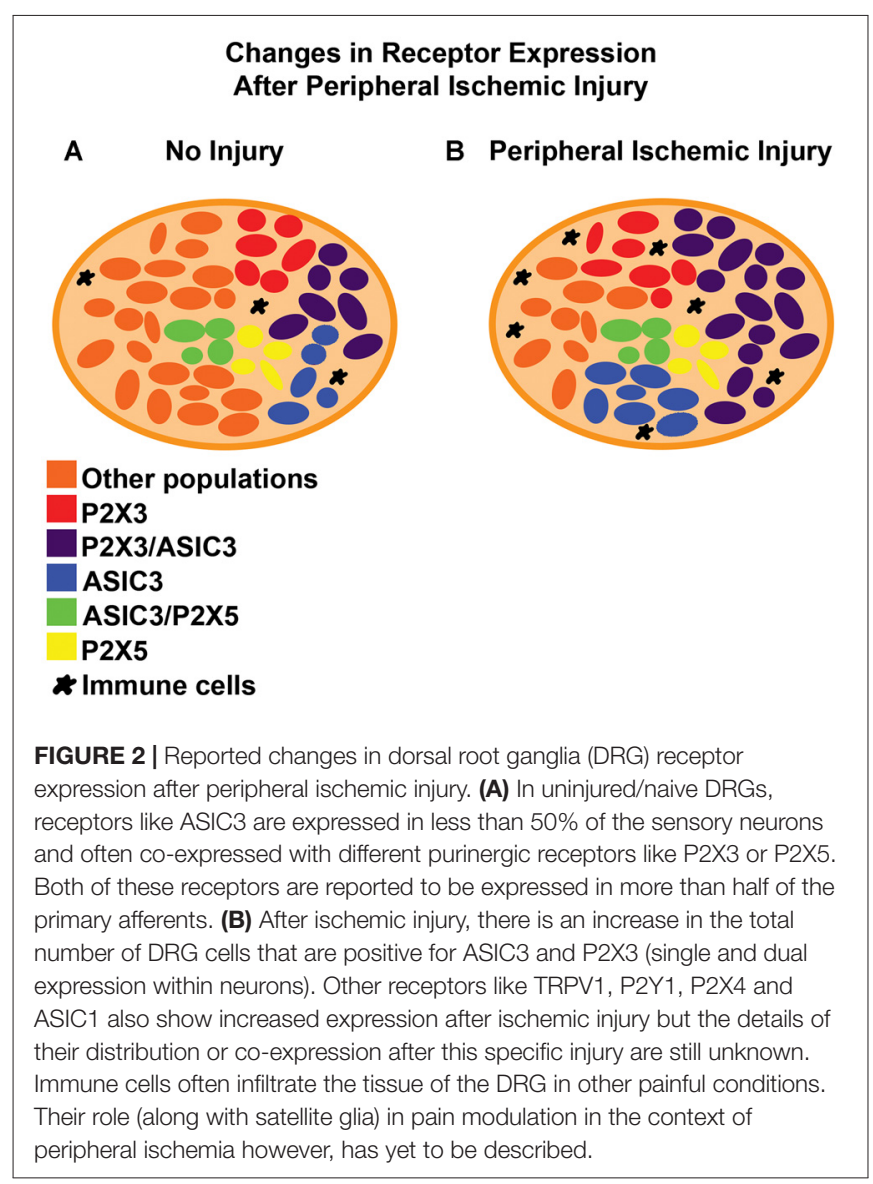

it's reasonable to suggest that TRPV1 also plays a role in the development of chronic pain in SCD. A model of thrombus induced ischemic pain (TIIP) also showed that there is increased expression of TRPV1 $24 \mathrm{~h}$ after injury (Xing et al., 2008, 2009), and DRG neurons recorded in vitro from these animals showed increased responses to capsaicin, a TRPV1 agonist, compared to neurons from sham animals. Also in this model, there was an increase in the sympathetic response to arterial injection of capsaicin in the animals exposed to femoral artery occlusion compared to controls. In another femoral occlusion model, the pressor response evoked by intra-arterial injection of capsaicin into the injured hind limb more than doubled the response elicited by the same injection in the contralateral, uninjured limb (Tsuchimochi et al., 2010). Collectively, this suggests a role for TRPV1 in both pain and EPR modulation post ischemia.

However, these findings are in contrast with other reports in which gene expression analysis in male mouse DRGs that innervate muscle tissue exposed to $\mathrm{I} / \mathrm{R}$ or prolonged $\mathrm{BAO}$ injury did not show changes in TRPV1 mRNA expression $24 \mathrm{~h}$ after injury (Ross et al., 2014). Increased phosphorylation of TRPV1 has been suggested as a mechanism for acid evoked thermal hyperalgesia in the previously described model of TIIP (Kwon et al., 2014) and these alternative modifications may be a reason for this discrepancy. Nevertheless, the response of cultured DRG neurons to different combinations of metabolites simulating an ischemic environment is not altered by the presence of the TRPV1 antagonist JYL-1433 and are only partially blocked by the TRPV 1 antagonist LJO-328 at doses that completely blocked the response to capsaicin in these neurons (Light et al., 2008). Future research on TRPV1 function in ischemic myalgia development and EPR modulation is therefore warranted.

There is ample evidence for the role of P2 receptors and how they affect afferent response to ischemia. As an example, the non-selective P2 receptor inhibitor PPADS, attenuates the EPR elicited by static contraction of the muscle (Kindig et al., 2007; McCord et al., 2010). Furthermore, usage of more specific P2X antagonists A-317491 and RO-3, had similar effects in the increased cardiovascular response induced either by static muscle contractions or by post-contraction ischemia (McCord et al., 2010). A similar effect of P2X channel antagonists on the EPR was also observed in a rat model of peripheral arterial insufficiency where blockade of the purinergic receptors prevented the enhanced EPR after ischemic injury (Stone et al., 2014). These channels also likely play an important role in modulating specific functional response properties of each afferent population. Immunocytochemical analysis of the functionally characterized DRG cells revealed that neurons responding to "low metabolites", do not express ASIC3 while the subpopulation of neurons that is activated by noxious, pain inducing "high metabolites" usually expresses ASIC3 or TRPV1 ion channels. P2X3 appeared to be expressed in both populations (Ross et al., 2014, 2016; Queme et al., 2016).

ASIC and P2X receptors may also be key players in the afferent sensitization that is observed after ischemic injury (Dunn et al., 2001; Immke and McCleskey, 2001; North, 2002, 2004; Yagi et al., 2006; Birdsong et al., 2010; Liu et al., 2011). These channels may mediate the perception of fatigue and ischemic pain under normal conditions (Light et al., 2008; Birdsong et al., 2010). The importance of their interactions sensing the intramuscular chemical environment is highlighted by the fact that neuronal responses to low concentrations of combined ATP, lactate and low $\mathrm{pH}$ are blocked by low concentrations of the $\mathrm{P} 2 \mathrm{X}$ antagonist trinitrophenyl-adenosine triphosphate (TNP-ATP). Low doses of this antagonist target only P2X5, suggesting it may play a role in sensing fatigue. At higher concentrations, TNP-ATP blocks responses to various concentrations of metabolites in the same way as the nonspecific P2 receptor antagonist PPADS (Light et al., 2008). This suggests that sensing of the more noxious "high metabolites" is dependent upon the combined action of different $\mathrm{P} 2 \mathrm{X}$ receptors.

The role of other P2X receptors in the development of ischemic myalgia is less clear. P2X3 is upregulated after $I / R$ injuries and the total number of positive neurons in the DRG innervating ischemia-affected muscle tissue are also increased (Cairns et al., 2003; Ross et al., 2014, 2016; Queme et al., 2016). The role of $\mathrm{P} 2 \mathrm{X} 3$ in muscle pain development however, has been linked to inflammation. P2X3 is highly expressed in both inflammatory and post-contraction models of masseter muscle pain (Noma et al., 2013; Tariba Knežević et al., 2016). The connection to inflammatory responses is strengthened by the fact that increased expression of P2X3 and 
the subsequent decrease in head withdrawal thresholds observed in the post-contraction muscle pain model can be prevented by injection of interleukin $1 \beta$ (IL1 $\beta$ ) antagonists into the affected muscle. Furthermore, injection of a P2X3 selective antagonist prevents the decreased head withdrawal threshold, suggesting that the mechanical hypersensitivity is due to P2X3 activity (Noma et al., 2013). P2X3 has further been proposed to modulate the EPR enhancement resulting from ischemic injury (McCord et al., 2010). Specific P2X3 subunit knock-down using antisense oligonucleotides decreases acute inflammation-induced mechanical and thermal hyperalgesia, as well as the mechanical allodynia observed after spinal nerve ligation (Barclay et al., 2002; Honore et al., 2002; North, 2004), suggesting a role for $\mathrm{P} 2 \mathrm{X} 3$ upregulation in the development of pain. However, these studies only assessed cutaneous pain-like behaviors. In the case of P2X4, there is an upregulation of mRNA extracted from whole DRG lysates, after I/R injury (Ross et al., 2014). Nonetheless, the expression profile of this receptor does not seem to be confined to the populations of small sensory neurons that are typically associated with nociception (Chen et al., 2016). Therefore, more research is needed to fully decipher the involvement, if any, of P2X4 on ischemic myalgia development and EPR regulation.

$\mathrm{P} 2 \mathrm{X}$ receptors also modulate the function of ASIC3, another key mediator of pain generation. Targeting this acid-sensing ion channel can effectively reduce muscle pain in different animal models (Sluka et al., 2007; Fujii et al., 2008; Walder et al., 2011; Ross et al., 2016). Multiple mechanisms have been proposed on how changes in the function of ASIC3 can lead to increased afferent sensitization; including increased expression (Dworkin et al., 1994; Liu et al., 2010; Ross et al., 2016), enhanced membrane translocation (Queme et al., 2016) and increased synergy with other receptors (Birdsong et al., 2010), specifically purinergic receptors. The selective ASIC3 antagonist A-317567 has also been found to be effective at preventing the neuronal responses to different concentration of metabolites suggesting that sensing ischemia requires both $\mathrm{P} 2 \mathrm{X}$ and ASIC3 activity. This interaction was later confirmed by an in vitro study showing that ATP enhances the response of ASIC3 to low $\mathrm{pH}$. In this report, only the interaction between $\mathrm{P} 2 \mathrm{X} 5$ and ASIC3 activation mimics the enhanced response to low $\mathrm{pH}$ and ATP that is observed in sensory neurons. Furthermore, about $25 \%$ of DRG neurons express P2X5 and of these neurons, about half co-express ASIC3 (Birdsong et al., 2010). While these findings are suggestive of possible modulation of ASIC3 sensitivity by P2X5, definitive confirmation in DRG neurons in vivo or ex vivo is still required.

In the specific context of ischemia, total DRG ASIC3 mRNA expression is increased in different injury models, and the total number of ASIC3 positive cells in the DRG increases (Queme et al., 2016; Ross et al., 2016). Moreover, the observed mechanical sensitization and the phenotypic switch in the metabolite response properties of DRG neurons that is observed after I/R is completely prevented (Ross et al., 2016). Both $\mathrm{P} 2 \mathrm{X}$ receptors and ASICs are key players in the sensory component of the EPR (McCord et al., 2009, 2010). The increased cardiovascular response to exercise observed during ischemic conditions (Tsuchimochi et al., 2010) is attenuated by the individual blockade of either ASICs or P2X receptors (Tsuchimochi et al., 2011; Stone et al., 2014) suggesting a role for these channels in dually regulating both pain and sympathetic reflexes after ischemia.

$\mathrm{P} 2 \mathrm{X}$ receptors are not the only purinergic receptors that are relevant after ischemic injuries. In a prolonged ischemia model, expression of the ADP sensitive, P2Y1 receptor, was found to be upregulated in the DRGs (Ross et al., 2014; Queme et al., 2016). Often associated with thermal hyperalgesia (Molliver et al., 2011; Jankowski et al., 2012; Queme et al., 2016), P2Y1 upregulation in the DRG was reported to modulate the increased pain related behaviors observed after ischemic insult (Queme et al., 2016). Similar results were found in the TIIP model, where blockade of P2Y1 with the selective antagonist MRS2179 prevented the induction of thermal hyperalgesia by low $\mathrm{pH}$ saline injections (Kwon et al., 2014). Altogether, these data suggest a diverse array of receptors and channels within group III and IV muscle afferents contribute to the development of pain and modulate the EPRs after peripheral ischemia.

\section{ROLE OF CYTOKINES AND GROWTH FACTORS IN ISCHEMIC MYALGIA DEVELOPMENT AND EPR MODULATION}

Ischemic injury alone does not likely drive all of the aforementioned changes in primary muscle afferents. Increased gene expression and concomitant afferent sensitization can also be linked to increased signaling from the damaged muscle tissue. Current evidence points at two important sources: cytokines and growth factors. These molecules are released into the intramuscular environment in response to the tissue damage caused by ischemia (Ascer et al., 1992a,b; Seekamp et al., 1993; Sternbergh et al., 1994; Emanueli et al., 2002; Turrini et al., 2002; Ross et al., 2014, 2016). These substances can trigger painful responses and induce peripheral afferent sensitization (Oprée and Kress, 2000; Airaksinen and Saarma, 2002; Obreja et al., 2002; Amaya et al., 2004; Makowska et al., 2005; Anand et al., 2006; Binshtok et al., 2008; Svensson et al., 2008; Yang et al., 2013; Ross et al., 2016). Some of the most common factors in this context are: nerve growth factor (NGF), glial cell line derived neurotrophic factor (GDNF) and inflammatory cytokines.

NGF has been frequently linked with the development of pain and hyperalgesia in various animal models and clinical conditions (Amaya et al., 2004; Price et al., 2005; Hoheisel et al., 2007; Hayashi et al., 2011). In the context of muscle ischemia, NGF plays an important role in the repair of both vasculature and muscle tissue (Emanueli et al., 2002; Turrini et al., 2002; Karatzas et al., 2013; Diao et al., 2016). At the same time, NGF has pro-nociceptive effects through modulation of the response properties of group III and IV afferents (Hoheisel et al., 2005; Ellrich and Makowska, 2007; Svensson et al., 2008; Murase et al., 2010). NGF also seems to play a role in the development of exacerbated EPRs during ischemia. Administration of anti-NGF antibodies can prevent the increase in arterial pressure and heart rate observed during exercise in the femoral artery ligation model (Lu et al., 2012). 
GDNF, another growth factor frequently tied to pain perception, is highly expressed in the muscles after ischemic injuries (Ross et al., 2014). It has been shown to induce muscle mechanical hyperalgesia after intense muscle contractions, and to potentiate afferent responses downstream of cyclo-oxygenase 2 signaling (Murase et al., 2013). Evidence of this comes from studies in male rats showing that mechanical hyperalgesia can be directly induced by intramuscular injection of GDNF. This increased response to mechanical stimulation can be reverted by administering the non-specific ASIC antagonist amiloride but not by capsazepine (Murase et al., 2014), suggesting that its sensitization effects are ASIC dependent with no involvement of TRPV1. So far, the relationship between GDNF and the EPR has not been studied. Nevertheless, previous research strongly suggests that NGF and GDNF signaling is an important component in the development of pain and increased cardiovascular responses after ischemic injuries.

One of the better characterized pro-nociceptive signals that is increased in injured muscles after ischemic injury is IL1 $\beta$. This cytokine has been associated with pain development in multiple models ranging from muscle overuse (Noma et al., 2013; Borghi et al., 2014), to inflammation (Wang et al., 2015) and nerve injury (Gui et al., 2016). IL1 $\beta$ levels are increased in muscle tissue after acute intense swimming (Borghi et al., 2014), and administration of an IL1 $\beta$ antagonist before and $12 \mathrm{~h}$ after exercise prevents the development of mechanical hyperalgesia (Borghi et al., 2014). These findings point to IL1 $\beta$ as an important molecule in the development of muscle pain after injury. In the context of ischemia, the IL1 $\beta$ receptor IL1r1, is also upregulated in the DRG (Ross et al., 2014). Preventing this upregulation through nerve targeted siRNA injections can prevent the development of pain-related behaviors in I/R-affected mice. This strategy is also effective in preventing I/R-induced group III and IV muscle afferent sensitization, as well as the phenotypic switch in the metabolite response properties of these neurons (Ross et al., 2016). While the pronociceptive qualities of IL1 $\beta$ are very well established, the role of cytokines in the modulation of the EPR during ischemia is still under investigation. One of the cytokines frequently associated with increased primary afferent responsiveness and pain, interleukin-6 (IL-6), has been linked with increased EPR in response to muscle contractions in a femoral ligation model (Copp et al., 2015). The contribution of cytokine signaling to changes in the EPR after ischemic injury is therefore an important question for future research that needs to be addressed.

Another possible site of action for these various cytokines and growth factors is the DRG itself. Reports have highlighted the contributions of glial cells through cytokine release in models of neuropathic pain (Mika et al., 2013). The modulation of pain transmission through regulation of purinergic receptors in glia has also been described (Villa et al., 2010). Increased macrophage infiltration in DRG can be linked to the development of pain after peripheral nerve injury due to their ability to release cytokines and growth factors (Scholz and Woolf, 2007; Zhang et al., 2016). These data suggest that immune cells and resident glia in the DRG could also play a significant role in the modulation of ischemic pain. Yet, the specific function, if any, of glia or other immune cells in the context of peripheral ischemic injuries is still unknown and should be the subject of future research.

\section{SEX DIFFERENCES IN PRIMARY MUSCLE AFFERENT SENSITIZATION AFTER ISCHEMIC INJURY}

Chronic pain conditions are more prevalent in women (Wijnhoven et al., 2006a,b; Greenspan et al., 2007; Bartley and Fillingim, 2013). Multiple clinical and basic studies have shown that females are more sensitive to noxious stimulation, and more likely to require greater amounts of opioids relative to body weight following trauma or surgery (Mogil et al., 1993; Bell et al., 1994; Riley et al., 1998; Kalkman et al., 2003; Craft et al., 2004; Fillingim and Gear, 2004; Greenspan et al., 2007; Mogil and Bailey, 2010; Bartley and Fillingim, 2013; Sadhasivam et al., 2015). Furthermore, men and women have differing genetic predispositions to pain sensitivity (Kindler et al., 2011; Belfer et al., 2013; Wieskopf et al., 2015), which have also been documented in animal models (Mogil and Belknap, 1997; Mogil et al., 1997, 2000, 2011; LaCroix-Fralish et al., 2005; Juni et al., 2010; Belfer et al., 2013).

Recent studies have provided evidence for sex-dependent immune reactions that lead to differential brain and spinal cord sensitization mechanisms in a variety of rodent injury models (Sorge et al., 2011, 2015; Posillico et al., 2015; Doyle et al., 2017), but little is known about how these processes may affect primary muscle afferent function. One study, analyzing male and female gastrocnemius afferents, found that contrary to in vivo behavioral results suggesting lower mechanical thresholds in females, mechanical thresholds were found to be significantly higher in females during patch clamp recordings of retrogradely labeled afferents (Hendrich et al., 2012). Additionally, sex differences in glutamate response within the primary muscle afferents have been described in both humans and rodents (Cairns et al., 2001); however, basic studies of sex effects on group III and IV muscle afferent plasticity, particularly following ischemic insult, have been limited. Because of known sexual dimorphisms in disease severity and long-term outcomes in multiple conditions linked to ischemic myalgia (Wijnhoven et al., 2006b; Bartley and Fillingim, 2013; Gommans et al., 2015), including the increased occurance of CRPS (de Mos et al., 2007) and FM in women (Gran, 2003), female subjects should be considered for inclusion in future studies of ischemic muscle pain.

In our own investigation of female muscle afferents, we have found distinct changes in gene expression within the affected DRGs following I/R. Whereas males show a robust upregulation of ASIC3 after I/R, which corresponded with alterations in behavior and afferent sensitivity (Ross et al., 2014, 2016), ASIC3 levels in females are not affected with this type of injury (Ross, 2017), suggesting that ASIC3 may not serve a similar role in I/R-induced plasticity in females as it does in males. Additionally, TRPV1 and TRPM8 were found to be substantially increased in females, but not males, 1 day after I/R, which may relate to sex- and injury-dependent changes in thermal 
responsiveness in individual group III and IV muscle afferents (Ross, 2017).

Interestingly, human and animal studies have shown that females also have decreased EPRs compared to males (Ettinger et al., 1996; Schmitt and Kaufman, 2003; Ives et al., 2013). As ASIC3 and TRPV1 have both been shown to be integral to this reflex (Kaufman and Hayes, 2002; Li et al., 2008; Xing et al., 2008, 2009, 2012; Mizuno et al., 2011; Kaufman, 2012), further investigation of the sex- and injury-dependent expression of these channels is crucial to understanding the contributions of group III and IV muscle afferents to both pain sensitivity and EPRs.

\section{CLINICAL SIGNIFICANCE}

Adequate management of the multiple complications in patients with ischemic injuries presents a variety of challenges. While patients with conditions like PVD and FM experience great benefits from an active lifestyle and physical therapy (Busch et al., 2011; Castro-Sánchez et al., 2013, 2014), in many cases the first barrier to therapy adherence is the underlying pain, sometimes so limiting that can lead to an excessively sedentary lifestyle. The decreased activity level that follows has also been linked with increased cardiovascular risk in FM patients (Su et al., 2015; Acosta-Manzano et al., 2017).

SCD presents different challenges. Many patients with this condition are children and teenagers (Wilson and Nelson, 2015). Advances in therapies have significantly improved the life expectancy of these patients but with longer life spans new complications have arisen. The repeated ischemic injuries derived from repeated vaso-occlusive crises during the lifespan do not only result in acute painful events but can develop into intractable chronic pain (Peters et al., 2005). Current therapeutic strategies focus mainly in the treatment of the acute ischemic events (Yawn et al., 2014). Classically, pain in this type of conditions has been managed using different regimes of opioid analgesic therapies (Chou et al., 2009). A case can be made for the use of opioids in the acute setting during a vaso-occlusive crisis in SCD. However, long-term use of this therapeutic approach not only incurs the risk of developing

\section{REFERENCES}

Acosta-Manzano, P., Segura-Jiménez, V., Estévez-López, F., ÁlvarezGallardo, I. C., Soriano-Maldonado, A., Borges-Cosic, M., et al. (2017). Do women with fibromyalgia present higher cardiovascular disease risk profile than healthy women? The al-Andalus project. Clin. Exp. Rheumatol. 35, 61-67.

Adreani, C. M., and Kaufman, M. P. (1998). Effect of arterial occlusion on responses of group III and IV afferents to dynamic exercise. J. Appl. Physiol. 84, 1827-1833.

Airaksinen, M. S., and Saarma, M. (2002). The GDNF family: signalling, biological functions and therapeutic value. Nat. Rev. Neurosci. 3, 383-394. doi: $10.1038 / \mathrm{nrn} 812$

Alam, M., and Smirk, F. H. (1937). Observations in man upon a blood pressure raising reflex arising from the voluntary muscles. J. Physiol. 89, 372-383. doi: 10.1113/jphysiol.1937.sp003485

Amaya, F., Shimosato, G., Nagano, M., Ueda, M., Hashimoto, S., Tanaka, Y., et al. (2004). NGF and GDNF differentially regulate TRPV1 expression dependence but may also be ineffective as a treatment of chronic pain (Peters et al., 2005; Painter and Crofford, 2013; Wilson and Nelson, 2015). Another clinically relevant issue is that sensitization of primary muscle afferents may occur in a sex-dependent manner and this may underlie the differing prevalence of chronic pain and cardiovascular dysfunction in men and women, which could have implications for preventative care and therapeutics.

\section{CONCLUDING REMARKS}

Skeletal muscle ischemia is a strong driver of peripheral afferent sensitization, exerting robust effects through complex signaling cascades, resulting in the development of deep tissue pain and altered EPRs (Figure 1). Multiple studies in animal models have shown a strong link in the role of group III and IV muscle afferents as nociceptors and chemoreceptors. These physiological responses to ischemic injury allow tissue repair by causing changes in tissue perfusion and prevent further damage by triggering painful responses to normal stimuli. How these basic mechanisms are tied to the development of chronic pain and altered EPRs is still under investigation. Research aimed at the basic mechanisms involved in the chronification of pain or EPR function in conditions that feature skeletal muscle ischemia need to be prioritized in order to guide the development of new therapies for these patients.

\section{AUTHOR CONTRIBUTIONS}

LFQ and MPJ planned the manuscript. LFQ and JLR analyzed the literature and wrote the manuscript with guidance from MPJ. All authors edited, read and approved the manuscript.

\section{FUNDING}

This research was supported by grants from the American Heart Association (LFQ: 16POST29750004) and the National Institutes of Health (NIH)/National Institute of Arthritis and Musculoskeletal and Skin Diseases (NIAMS) (MPJ: R01AR064551; JLR: F31AR068896). that contributes to development of inflammatory thermal hyperalgesia. Eur. J. Neurosci. 20, 2303-2310. doi: 10.1111/j.1460-9568.2004.03701.x

Ambrose, K. R., and Golightly, Y. M. (2015). Physical exercise as non-pharmacological treatment of chronic pain: why and when. Best Pract. Res. Clin. Rheumatol. 29, 120-130. doi: 10.1016/j.berh.2015.04.022

Anand, U., Otto, W. R., Casula, M. A., Day, N. C., Davis, J. B., Bountra, C., et al. (2006). The effect of neurotrophic factors on morphology, TRPV1 expression and capsaicin responses of cultured human DRG sensory neurons. Neurosci. Lett. 399, 51-56. doi: 10.1016/j.neulet.2006.01.046

Andersen, J. H., and Gaardboe, O. (1993). Prevalence of persistent neck and upper limb pain in a historical cohort of sewing machine operators. Am. J. Ind. Med. 24, 677-687. doi: 10.1002/ajim.4700240604

Andres, K. H., von During, M., and Schmidt, R. F. (1985). Sensory innervation of the Achilles tendon by group III and IV afferent fibers. Anat. Embryol. 172, 145-156. doi: 10.1007/bf00319597

Ascer, E., Gennaro, M., Cupo, S., and Mohan, C. (1992a). Do cytokines play a role in skeletal muscle ischemia and reperfusion? J. Cardiovasc. Surg. 33, 588-592. 
Ascer, E., Mohan, C., Gennaro, M., and Cupo, S. (1992b). Interleukin-1 and thromboxane release after skeletal muscle ischemia and reperfusion. Ann. Vasc. Surg. 6, 69-73. doi: 10.1007/bf02000671

Baccelli, G., Reggiani, P., Mattioli, A., Corbellini, E., Garducci, S., and Catalano, M. (1999). The exercise pressor reflex and changes in radial arterial pressure and heart rate during walking in patients with arteriosclerosis obliterans. Angiology 50, 361-374. doi: 10.1177/000331979905000502

Bacurau, A. V., Cunha, T. F., Souza, R. W., Voltarelli, V. A., Gabriel-Costa, D., and Brum, P. C. (2016). Aerobic exercise and pharmacological therapies for skeletal myopathy in heart failure: similarities and differences. Oxid. Med. Cell. Longev. 2016:4374671. doi: 10.1155/2016/4374671

Banic, B., Petersen-Felix, S., Andersen, O. K., Radanov, B. P., Villiger, P. M., Arendt-Nielsen, L., et al. (2004). Evidence for spinal cord hypersensitivity in chronic pain after whiplash injury and in fibromyalgia. Pain 107, 7-15. doi: 10.1016/j.pain.2003.05.001

Barclay, J., Patel, S., Dorn, G., Wotherspoon, G., Moffatt, S., Eunson, L., et al. (2002). Functional downregulation of $\mathrm{P}_{2} \mathrm{X}_{3}$ receptor subunit in rat sensory neurons reveals a significant role in chronic neuropathic and inflammatory pain. J. Neurosci. 22, 8139-8147.

Bartley, E. J., and Fillingim, R. B. (2013). Sex differences in pain: a brief review of clinical and experimental findings. Br. J. Anaesth. 111, 52-58. doi: 10.1093/bja/aet127

Bartur, G., Vatine, J. J., Raphaely-Beer, N., Peleg, S., and Katz-Leurer, M. (2014). Heart rate autonomic regulation system at rest and during paced breathing among patients with CRPS as compared to age-matched healthy controls. Pain Med. 15, 1569-1574. doi: 10.1111/pme.12449

Beard, J. D. (2000). Chronic lower limb ischemia. West. J. Med. 173, 60-63. doi: 10.1136/ewjm.173.1.60

Belfer, I., Segall, S. K., Lariviere, W. R., Smith, S. B., Dai, F., Slade, G. D., et al. (2013). Pain modality- and sex-specific effects of COMT genetic functional variants. Pain 154, 1368-1376. doi: 10.1016/j.pain.2013.04.028

Bell, M. R., Garratt, K. N., Bresnahan, J. F., and Holmes, D. R. Jr. (1994). Immediate and long-term outcome after directional coronary atherectomy: analysis of gender differences. Mayo Clin. Proc. 69, 723-729. doi: 10.1016/s00256196(12)61088-x

Bergman, S., Herrström, P., Högström, K., Petersson, I. F., Svensson, B., and Jacobsson, L. T. (2001). Chronic musculoskeletal pain, prevalence rates and sociodemographic associations in a Swedish population study. J. Rheumatol. 28, 1369-1377.

Binshtok, A. M., Wang, H., Zimmermann, K., Amaya, F., Vardeh, D., Shi, L., et al. (2008). Nociceptors are interleukin-1 $\beta$ sensors. J. Neurosci. 28, 14062-14073. doi: 10.1523/JNEUROSCI.3795-08.2008

Birdsong, W. T., Fierro, L., Williams, F. G., Spelta, V., Naves, L. A., Knowles, M., et al. (2010). Sensing muscle ischemia: coincident detection of acid and ATP via interplay of two ion channels. Neuron 68, 739-749. doi: 10.1016/j.neuron. 2010.09.029

Blaisdell, F. W. (2002). The pathophysiology of skeletal muscle ischemia and the reperfusion syndrome: a review. Cardiovasc. Surg. 10, 620-630. doi: 10.1016/s0967-2109(02)00070-4

Bliddal, H., and Danneskiold-Samsoe, B. (2007). Chronic widespread pain in the spectrum of rheumatological diseases. Best Pract. Res. Clin. Rheumatol. 21, 391-402. doi: 10.1016/j.berh.2007.03.005

Bonica, J. J. (1954). The management of pain. South. Med. J. 47:802. doi: 10.1097/00007611-195408000-00042

Bonica, J. J. (1990). "Causalgia and other reflex sympathetic dystrophies," in Management of Pain, eds J. J. Bonica, J. D. Loeser, C. R. Chapman and W. E. Fordyce (Philadelphia, PA: Lea and Feibiger), 220-243.

Borghi, S. M., Zarpelon, A. C., Pinho-Ribeiro, F. A., Cardoso, R. D., Cunha, T. M., Alves-Filho, J. C., et al. (2014). Targeting interleukin-1 $\beta$ reduces intense acute swimming-induced muscle mechanical hyperalgesia in mice. J. Pharm. Pharmacol. 66, 1009-1020. doi: 10.1111/jphp.12226

Bou-Maroun, L. M., Meta, F., Hanba, C. J., Campbell, A. D., and Yanik, G. A. (2018). An analysis of inpatient pediatric sickle cell disease: incidence, costs, and outcomes. Pediatr. Blood Cancer 65:e26758. doi: 10.1002/pbc. 26758

Brandow, A. M., Stucky, C. L., Hillery, C. A., Hoffmann, R. G., and Panepinto, J. A. (2013). Patients with sickle cell disease have increased sensitivity to cold and heat. Am. J. Hematol. 88, 37-43. doi: 10.1002/ajh.23341
Buckwalter, J. A. (2003). Sports, joint injury, and posttraumatic osteoarthritis. J. Orthop. Sports Phys. Ther. 33, 578-588. doi: 10.2519/jospt.2003.33. 10.578

Busch, A. J., Webber, S. C., Brachaniec, M., Bidonde, J., Bello-Haas, V. D., Danyliw, A. D., et al. (2011). Exercise therapy for fibromyalgia. Curr. Pain Headache Rep. 15, 358-367. doi: 10.1007/s11916-011-0214-2

Cairns, B. E., Hu, J. W., Arendt-Nielsen, L., Sessle, B. J., and Svensson, P. (2001). Sex-related differences in human pain and rat afferent discharge evoked by injection of glutamate into the masseter muscle. J. Neurophysiol. 86, 782-791. doi: $10.1152 /$ jn.2001.86.2.782

Cairns, B. E., Svensson, P., Wang, K., Hupfeld, S., Graven-Nielsen, T., Sessle, B. J., et al. (2003). Activation of peripheral NMDA receptors contributes to human pain and rat afferent discharges evoked by injection of glutamate into the masseter muscle. J. Neurophysiol. 90, 2098-2105. doi: 10.1152/jn. 00353.2003

Castro-Sánchez, A. M., Aguilar-Ferrándiz, M. E., Matarán-Peñarrocha, G. A., Sánchez-Joya Mdel, M., Arroyo-Morales, M., and Fernández-de-las-Peñas, C. (2014). Short-term effects of a manual therapy protocol on pain, physical function, quality of sleep, depressive symptoms and pressure sensitivity in women and men with fibromyalgia syndrome: a randomized controlled trial. Clin. J. Pain 30, 589-597. doi: 10.1097/AJP.0000000000000008

Castro-Sánchez, A. M., Matarán-Peñarrocha, G. A., Feriche-FernándezCastanys, B., Fernández-Sola, C., Sánchez-Labraca, N., and MorenoLorenzo, C. (2013). A program of 3 physical therapy modalities improves peripheral arterial disease in diabetes type 2 patients: a randomized controlled trial. J. Cardiovasc. Nurs. 28, 74-82. doi: 10.1097/JCN.0b013e318239f419

Chalaye, P., Lafrenaye, S., Goffaux, P., and Marchand, S. (2014). The role of cardiovascular activity in fibromyalgia and conditioned pain modulation. Pain 155, 1064-1069. doi: 10.1016/j.pain.2013.12.023

Chen, L., Liu, Y. W., Yue, K., Ru, Q., Xiong, Q., Ma, B. M., et al. (2016) Differential expression of ATP-gated P2X receptors in DRG between chronic neuropathic pain and visceralgia rat models. Purinergic Signal. 12, 79-87. doi: 10.1007/s11302-015-9481-4

Chou, R., Fanciullo, G. J., Fine, P. G., Adler, J. A., Ballantyne, J. C. Davies, P., et al. (2009). Clinical guidelines for the use of chronic opioid therapy in chronic noncancer pain. J. Pain 10, 113-130. doi: 10.1016/j.jpain 2008.10.008

Clauw, D. J. (2015). Diagnosing and treating chronic musculoskeletal pain based on the underlying mechanism(s). Best Pract. Res. Clin. Rheumatol. 29, 6-19. doi: 10.1016/j.berh.2015.04.024

Cobos, E. J., Ghasemlou, N., Araldi, D., Segal, D., Duong, K., and Woolf, C. J. (2012). Inflammation-induced decrease in voluntary wheel running in mice: a nonreflexive test for evaluating inflammatory pain and analgesia. Pain 153, 876-884. doi: 10.1016/j.pain.2012.01.016

Coderre, T. J., and Bennett, G. J. (2010). A hypothesis for the cause of complex regional pain syndrome-type I (reflex sympathetic dystrophy): pain due to deep-tissue microvascular pathology. Pain Med. 11, 1224-1238. doi: 10.1111/j. 1526-4637.2010.00911.x

Coderre, T. J., Xanthos, D. N., Francis, L., and Bennett, G. J. (2004). Chronic post-ischemia pain (CPIP): a novel animal model of complex regional pain syndrome-type I (CRPS-I; reflex sympathetic dystrophy) produced by prolonged hindpaw ischemia and reperfusion in the rat. Pain 112, 94-105. doi: 10.1016/j.pain.2004.08.001

Copp, S. W., Stone, A. J., Li, J., and Kaufman, M. P. (2015). Role played by interleukin-6 in evoking the exercise pressor reflex in decerebrate rats: effect of femoral artery ligation. Am. J. Physiol. Heart Circ. Physiol. 309, H166-H173. doi: 10.1152/ajpheart.00195.2015

Craft, R. M., Mogil, J. S., and Aloisi, A. M. (2004). Sex differences in pain and analgesia: the role of gonadal hormones. Eur. J. Pain 8, 397-411. doi: 10.1016/j. ejpain.2004.01.003

Curatolo, M., Arendt-Nielsen, L., and Petersen-Felix, S. (2004). Evidence, mechanisms, and clinical implications of central hypersensitivity in chronic pain after whiplash injury. Clin. J. Pain 20, 469-476. doi: 10.1097/00002508200411000-00013

Davies, M. G. (2012). Criticial limb ischemia: epidemiology. Methodist Debakey Cardiovasc. J. 8, 10-14. doi: 10.14797/mdcj-8-4-10

De Inocencio, J. (2004). Epidemiology of musculoskeletal pain in primary care. Arch. Dis. Child. 89, 431-434. doi: 10.1136/adc.2003.028860 
de Mos, M., de Bruijn, A. G., Huygen, F. J., Dieleman, J. P., Stricker, B. H., and Sturkenboom, M. C. (2007). The incidence of complex regional pain syndrome: a population-based study. Pain 129, 12-20. doi: 10.1016/j.pain.2006. 09.008

Debold, E. P. (2015). Potential molecular mechanisms underlying muscle fatigue mediated by reactive oxygen and nitrogen species. Front. Physiol. 6:239. doi: 10.3389/fphys.2015.00239

Delliaux, S., Brerro-Saby, C., Steinberg, J. G., and Jammes, Y. (2009). Reactive oxygen species activate the group IV muscle afferents in resting and exercising muscle in rats. Pflugers Arch. 459, 143-150. doi: 10.1007/s00424-009-0713-8

Dennis, G. J., and Keating, R. M. (1991). Muscle infarction in sickle cell anemia. Ann. Intern. Med. 115, 831-832. doi: 10.7326/0003-4819-115-10-831

Diao, Y. P., Cui, F. K., Yan, S., Chen, Z. G., Lian, L. S., Guo, L. L., et al. (2016). Nerve growth factor promotes angiogenesis and skeletal muscle fiber remodeling in a murine model of hindlimb ischemia. Chin. Med. J. 129, 313-319. doi: 10.4103/0366-6999.174496

Doyle, H. H., Eidson, L. N., Sinkiewicz, D. M., and Murphy, A. Z. (2017). Sex differences in microglia activity within the periaqueductal gray of the rat: a potential mechanism driving the dimorphic effects of morphine. J. Neurosci. 37, 3202-3214. doi: 10.1523/JNEUROSCI.2906-16.2017

Dunn, P. M., Zhong, Y., and Burnstock, G. (2001). P2X receptors in peripheral neurons. Prog. Neurobiol. 65, 107-134. doi: 10.1016/s0301-0082(01)00005-3

Dworkin, B. R., Elbert, T., Rau, H., Birbaumer, N., Pauli, P., Droste, C., et al. (1994). Central effects of baroreceptor activation in humans: attenuation of skeletal reflexes and pain perception. Proc. Natl. Acad. Sci. U S A 91, 6329-6333. doi: 10.1073/pnas.91.14.6329

Eisenhardt, S. U., Schmidt, Y., Karaxha, G., Iblher, N., Penna, V., TorioPadron, N., et al. (2012). Monitoring molecular changes induced by ischemia/reperfusion in human free muscle flap tissue samples. Ann. Plast. Surg. 68, 202-208. doi: 10.1097/SAP.0b013e3181f77ba5

Ellrich, J., and Makowska, A. (2007). Nerve growth factor and ATP excite different neck muscle nociceptors in anaesthetized mice. Cephalalgia 27, 1226-1235. doi: 10.1111/j.1468-2982.2007.01431.x

Elvin, A., Siösteen, A. K., Nilsson, A., and Kosek, E. (2006). Decreased muscle blood flow in fibromyalgia patients during standardised muscle exercise: a contrast media enhanced colour Doppler study. Eur. J. Pain 10, 137-144. doi: 10.1016/j.ejpain.2005.02.001

Emanueli, C., Salis, M. B., Pinna, A., Graiani, G., Manni, L., and Madeddu, P. (2002). Nerve growth factor promotes angiogenesis and arteriogenesis in ischemic hindlimbs. Circulation 106, 2257-2262. doi: 10.1161/01.cir. 0000033971.56802.c5

Ettinger, S. M., Silber, D. H., Collins, B. G., Gray, K. S., Sutliff, G., Whisler, S. K., et al. (1996). Influences of gender on sympathetic nerve responses to static exercise. J. Appl. Physiol. 80, 245-251. doi: 10.1152/jappl.1996.80.1.245

Fillingim, R. B., and Gear, R. W. (2004). Sex differences in opioid analgesia: clinical and experimental findings. Eur. J. Pain 8, 413-425. doi: 10.1016/j.ejpain.2004. 01.007

Fujii, Y., Ozaki, N., Taguchi, T., Mizumura, K., Furukawa, K., and Sugiura, Y. (2008). TRP channels and ASICs mediate mechanical hyperalgesia in models of inflammatory muscle pain and delayed onset muscle soreness. Pain 140, 292-304. doi: 10.1016/j.pain.2008.08.013

Garrison, S. R., Kramer, A. A., Gerges, N. Z., Hillery, C. A., and Stucky, C. L. (2012). Sickle cell mice exhibit mechanical allodynia and enhanced responsiveness in light touch cutaneous mechanoreceptors. Mol. Pain 8:62. doi: 10.1186/1744-8069-8-62

Gaskin, D. J., and Richard, P. (2012). The economic costs of pain in the United States. J. Pain 13, 715-724. doi: 10.1016/j.jpain.2012.03.009

Gautam, M., Benson, C. J., and Sluka, K. A. (2010). Increased response of muscle sensory neurons to decreases in $\mathrm{pH}$ after muscle inflammation. Neuroscience 170, 893-900. doi: 10.1016/j.neuroscience.2010.08.003

Gibbons, D. D., Kutschke, W. J., Weiss, R. M., and Benson, C. J. (2015). Heart failure induces changes in acid-sensing ion channels in sensory neurons innervating skeletal muscle. J. Physiol. 593, 4575-4587. doi: 10.1113/JP270690

Gillani, S., Cao, J., Suzuki, T., and Hak, D. J. (2012). The effect of ischemia reperfusion injury on skeletal muscle. Injury 43, 670-675. doi: 10.1016/j.injury. 2011.03.008

Gommans, L. N., Scheltinga, M. R., van Sambeek, M. R., Maas, A. H., Bendermacher, B. L., and Teijink, J. A. (2015). Gender differences following supervised exercise therapy in patients with intermittent claudication. J. Vasc. Surg. 62, 681-688. doi: 10.1016/j.jvs.2015.03.076

Grace, P. M., Strand, K. A., Maier, S. F., and Watkins, L. R. (2014). Suppression of voluntary wheel running in rats is dependent on the site of inflammation: evidence for voluntary running as a measure of hind paw-evoked pain. J. Pain 15, 121-128. doi: 10.1016/j.jpain.2013.10.001

Gran, J. T. (2003). The epidemiology of chronic generalized musculoskeletal pain. Best Pract. Res. Clin. Rheumatol. 17, 547-561. doi: 10.1016/s15216942(03)00042-1

Graven-Nielsen, T., and Mense, S. (2001). The peripheral apparatus of muscle pain: evidence from animal and human studies. Clin. J. Pain 17, 2-10. doi: 10.1097/00002508-200103000-00002

Graven-Nielsen, T., Mense, S., and Arendt-Nielsen, L. (2004). Painful and non-painful pressure sensations from human skeletal muscle. Exp. Brain Res. 159, 273-283. doi: 10.1007/s00221-004-1937-7

Greenspan, J. D., Craft, R. M., LeResche, L., Arendt-Nielsen, L., Berkley, K. J., Fillingim, R. B., et al. (2007). Studying sex and gender differences in pain and analgesia: a consensus report. Pain 132, S26-S45. doi: 10.1016/j.pain.2007. 10.014

Gregory, N. S., Whitley, P. E., and Sluka, K. A. (2015). Effect of intramuscular protons, lactate, and ATP on muscle hyperalgesia in rats. PLoS One 10:e0138576. doi: 10.1371/journal.pone.0138576

Groenewald, C. B., Essner, B. S., Wright, D., Fesinmeyer, M. D., and Palermo, T. M. (2014). The economic costs of chronic pain among a cohort of treatmentseeking adolescents in the United States. J. Pain 15, 925-933. doi: 10.1016/j. jpain.2014.06.002

Groeneweg, G., Huygen, F. J., Coderre, T. J., and Zijlstra, F. J. (2009). Regulation of peripheral blood flow in complex regional pain syndrome: clinical implication for symptomatic relief and pain management. BMC Musculoskelet. Disord. 10:116. doi: 10.1186/1471-2474-10-116

Gui, W. S., Wei, X., Mai, C. L., Murugan, M., Wu, L. J., Xin, W. J., et al. (2016). Interleukin-1 $\beta$ overproduction is a common cause for neuropathic pain, memory deficit and depression following peripheral nerve injury in rodents. Mol. Pain 12:1744806916646784. doi: 10.1177/1744806916646784

Hands, L. J., Sharif, M. H., Payne, G. S., Morris, P. J., and Radda, G. K. (1990). Muscle ischaemia in peripheral vascular disease studied by 31P-magnetic resonance spectroscopy. Eur. J. Vasc. Surg. 4, 637-642. doi: 10.1016/s0950$821 x(05) 80821-7$

Haouzi, P., Hill, J. M., Lewis, B. K., and Kaufman, M. P. (1999). Responses of group III and IV muscle afferents to distension of the peripheral vascular bed. J. Appl. Physiol. 87, 545-553.

Haouzi, P., Huszczuk, A., Gille, J. P., Chalon, B., Marchal, F., Crance, J. P., et al. (1995). Vascular distension in muscles contributes to respiratory control in sheep. Respir. Physiol. 99, 41-50. doi: 10.1016/0034-5687(94)00083-c

Hayashi, K., Ozaki, N., Kawakita, K., Itoh, K., Mizumura, K., Furukawa, K., et al. (2011). Involvement of NGF in the rat model of persistent muscle pain associated with taut band. J. Pain 12, 1059-1068. doi: 10.1016/j.jpain.2011. 04.010

Hayes, S. G., McCord, J. L., and Kaufman, M. P. (2008). Role played by P2X and P2Y receptors in evoking the muscle chemoreflex. J. Appl. Physiol. 104, 538-541. doi: 10.1152/japplphysiol.00929.2007

Hendrich, J., Alvarez, P., Joseph, E. K., Ferrari, L. F., Chen, X., and Levine, J. D. (2012). In vivo and in vitro comparison of female and male nociceptors. J. Pain 13, 1224-1231. doi: 10.1016/j.jpain.2012.09.009

Hillery, C. A., Kerstein, P. C., Vilceanu, D., Barabas, M. E., Retherford, D., Brandow, A. M., et al. (2011). Transient receptor potential vanilloid 1 mediates pain in mice with severe sickle cell disease. Blood 118, 3376-3383. doi: 10.1182/blood-2010-12-327429

Hoheisel, U., Unger, T., and Mense, S. (2005). Excitatory and modulatory effects of inflammatory cytokines and neurotrophins on mechanosensitive group IV muscle afferents in the rat. Pain 114, 168-176. doi: 10.1016/j.pain.2004. 12.020

Hoheisel, U., Unger, T., and Mense, S. (2007). Sensitization of rat dorsal horn neurons by NGF-induced subthreshold potentials and low-frequency activation. A study employing intracellular recordings in vivo. Brain Res. 1169 , 34-43. doi: 10.1016/j.brainres.2007.06.054

Honore, P., Mikusa, J., Bianchi, B., McDonald, H., Cartmell, J., Faltynek, C., et al. (2002). TNP-ATP, a potent $\mathrm{P}_{2} \mathrm{X}_{3}$ receptor antagonist, blocks acetic 
acid-induced abdominal constriction in mice: comparison with reference analgesics. Pain 96, 99-105. doi: 10.1016/s0304-3959(01)00434-1

Immke, D. C., and McCleskey, E. W. (2001). ASIC3: a lactic acid sensor for cardiac pain. ScientificWorldJournal 1, 510-512. doi: 10.1100/tsw.2001.254

Iolascon, G., de Sire, A., Moretti, A., and Gimigliano, F. (2015). Complex regional pain syndrome (CRPS) type I: historical perspective and critical issues. Clin. Cases Miner. Bone Metab. 12, 4-10. doi: 10.11138/ccmbm/2015.12.3s.004

Issberner, U., Reeh, P. W., and Steen, K. H. (1996). Pain due to tissue acidosis: a mechanism for inflammatory and ischemic myalgia? Neurosci. Lett. 208, 191-194. doi: 10.1016/0304-3940(96)12576-3

Ives, S. J., McDaniel, J., Witman, M. A., and Richardson, R. S. (2013). Passive limb movement: evidence of mechanoreflex sex specificity. Am. J. Physiol. Heart Circ. Physiol. 304, H154-H161. doi: 10.1152/ajpheart.00532.2012

Iwamoto, G. A., Waldrop, T. G., Kaufman, M. P., Botterman, B. R., Rybicki, K. J., and Mitchell, J. H. (1985). Pressor reflex evoked by muscular contraction: contributions by neuraxis levels. J. Appl. Physiol. 59, 459-467.

Jänig, W., and Baron, R. (2003). Complex regional pain syndrome: mystery explained? Lancet Neurol. 2, 687-697. doi: 10.1016/s1474-4422(03)00557-x

Jankowski, M. P., Rau, K. K., Ekmann, K. M., Anderson, C. E., and Koerber, H. R. (2013). Comprehensive phenotyping of group III and IV muscle afferents in mouse. J. Neurophysiol. 109, 2374-2381. doi: 10.1152/jn.01067.2012

Jankowski, M. P., Rau, K. K., Soneji, D. J., Ekmann, K. M., Anderson, C. E., Molliver, D. C., et al. (2012). Purinergic receptor P2Y1 regulates polymodal C-fiber thermal thresholds and sensory neuron phenotypic switching during peripheral inflammation. Pain 153, 410-419. doi: 10.1016/j.pain.2011.10.042

Jeschonneck, M., Grohmann, G., Hein, G., and Sprott, H. (2000). Abnormal microcirculation and temperature in skin above tender points in patients with fibromyalgia. Rheumatology 39, 917-921. doi: 10.1093/rheumatology/39.8.917

Juni, A., Cai, M., Stankova, M., Waxman, A. R., Arout, C., Klein, G., et al. (2010). Sex-specific mediation of opioid-induced hyperalgesia by the melanocortin-1 receptor. Anesthesiology 112, 181-188. doi: 10.1097/ALN.0b013e3181c53849

Kalkman, C. J., Visser, K., Moen, J., Bonsel, G. J., Grobbee, D. E., and Moons, K. G. (2003). Preoperative prediction of severe postoperative pain. Pain 105, 415-423. doi: 10.1016/s0304-3959(03)00252-5

Karatzas, A., Katsanos, K., Lilis, I., Papadaki, H., Kitrou, P., Lecht, S., et al. (2013). NGF promotes hemodynamic recovery in a rabbit hindlimb ischemic model through trkA- and VEGFR2-dependent pathways. J. Cardiovasc. Pharmacol. 62, 270-277. doi: 10.1097/FJC.0b013e3182982de7

Kasikcioglu, E., Dinler, M., and Berker, E. (2006). Reduced tolerance of exercise in fibromyalgia may be a consequence of impaired microcirculation initiated by deficient action of nitric oxide. Med. Hypotheses 66, 950-952. doi: 10.1016/j. mehy.2005.11.028

Katz, D. L., Greene, L., Ali, A., and Faridi, Z. (2007). The pain of fibromyalgia syndrome is due to muscle hypoperfusion induced by regional vasomotor dysregulation. Med. Hypotheses 69, 517-525. doi: 10.1016/j.mehy.2005.10.037

Kaufman, M. P. (2012). The exercise pressor reflex in animals. Exp. Physiol. 97, 51-58. doi: 10.1113/expphysiol.2011.057539

Kaufman, M. P., and Hayes, S. G. (2002). The exercise pressor reflex. Clin. Auton. Res. 12, 429-439. doi: 10.1007/s10286-002-0059-1

Kaufman, M. P., Rybicki, K. J., Waldrop, T. G., and Ordway, G. A. (1984). Effect of ischemia on responses of group III and IV afferents to contraction. J. Appl. Physiol. Respir. Environ. Exerc. Physiol. 57, 644-650.

Kehl, L. J., Trempe, T. M., and Hargreaves, K. M. (2000). A new animal model for assessing mechanisms and management of muscle hyperalgesia. Pain 85, 333-343. doi: 10.1016/s0304-3959(99)00282-1

Kidd, B. L. (2006). Osteoarthritis and joint pain. Pain 123, 6-9. doi: 10.1016/j.pain. 2006.04.009

Kindig, A. E., Hayes, S. G., and Kaufman, M. P. (2007). Blockade of purinergic 2 receptors attenuates the mechanoreceptor component of the exercise pressor reflex. Am. J. Physiol. Heart Circ. Physiol. 293, H2995-H3000. doi: 10.1152/ajpheart.00743.2007

Kindler, L. L., Sibille, K. T., Glover, T. L., Staud, R., Riley, J. L. III., and Fillingim, R. B. (2011). Drug response profiles to experimental pain are opioid and pain modality specific. J. Pain 12, 340-351. doi: 10.1016/j.jpain.2010.07.011

Kumazawa, T., and Mizumura, K. (1976). The polymodal C-fiber receptor in the muscle of the dog. Brain Res. 101, 589-593. doi: 10.1016/0006-8993(76)90483-2

Kwon, S. G., Roh, D. H., Yoon, S. Y., Moon, J. Y., Choi, S. R., Choi, H. S., et al. (2014). Acid evoked thermal hyperalgesia involves peripheral P2Y1 receptor mediated TRPV1 phosphorylation in a rodent model of thrombus induced ischemic pain. Mol. Pain 10:2. doi: 10.1186/1744-8069-10-2

LaCroix-Fralish, M. L., Rutkowski, M. D., Weinstein, J. N., Mogil, J. S., and Deleo, J. A. (2005). The magnitude of mechanical allodynia in a rodent model of lumbar radiculopathy is dependent on strain and sex. Spine 30, 1821-1827. doi: 10.1097/01.brs.0000174122.63291.38

Laferrière, A., Millecamps, M., Xanthos, D. N., Xiao, W. H., Siau, C., de Mos, M., et al. (2008). Cutaneous tactile allodynia associated with microvascular dysfunction in muscle. Mol. Pain 4:49. doi: 10.1186/1744-8069-4-49

Lee, Y. S., Jang, H. S., Kim, J. M., Lee, J. S., Lee, J. Y., Li Kim, K., et al. (2005). Adenoviral-mediated delivery of early growth response factor-1 gene increases tissue perfusion in a murine model of hindlimb ischemia. Mol. Ther. 12, 328-336. doi: 10.1016/j.ymthe.2005.03.027

Li, J., Gao, Z., Kehoe, V., Xing, J., King, N., and Sinoway, L. (2008). Interstitial adenosine triphosphate modulates muscle afferent nerve-mediated pressor reflex. Muscle Nerve 38, 972-977. doi: 10.1002/mus.21014

Li, J., and Xing, J. (2012). Muscle afferent receptors engaged in augmented sympathetic responsiveness in peripheral artery disease. Front. Physiol. 3:247. doi: $10.3389 /$ fphys.2012.00247

Li, J., Xing, J., and Lu, J. (2014). Nerve growth factor, muscle afferent receptors and autonomic responsiveness with femoral artery occlusion. J. Mod. Physiol. Res. $1,1-18$.

Light, A. R., Hughen, R. W., Zhang, J., Rainier, J., Liu, Z., and Lee, J. (2008). Dorsal root ganglion neurons innervating skeletal muscle respond to physiological combinations of protons, ATP, and lactate mediated by ASIC, P2X, and TRPV1. J. Neurophysiol. 100, 1184-1201. doi: 10.1152/jn. 01344.2007

Light, A. R., White, A. T., Hughen, R. W., and Light, K. C. (2009). Moderate exercise increases expression for sensory, adrenergic, and immune genes in chronic fatigue syndrome patients but not in normal subjects. J. Pain 10, 1099-1112. doi: 10.1016/j.jpain.2009.06.003

Liu, J., Gao, Z., and Li, J. (2010). Femoral artery occlusion increases expression of ASIC3 in dorsal root ganglion neurons. Am. J. Physiol. Heart Circ. Physiol. 299, H1357-H1364. doi: 10.1152/ajpheart.00612.2010

Liu, J., Li, J. D., Lu, J., Xing, J., and Li, J. (2011). Contribution of nerve growth factor to upregulation of $\mathrm{P} 2 \mathrm{X}_{3}$ expression in DRG neurons of rats with femoral artery occlusion. Am. J. Physiol. Heart Circ. Physiol. 301, H1070-H1079. doi: 10.1152/ajpheart.00188.2011

Loram, L. C., Mitchell, D., and Fuller, A. (2005). Rofecoxib and tramadol do not attenuate delayed-onset muscle soreness or ischaemic pain in human volunteers. J. Stroke Cerebrovasc. Dis. 83, 1137-1145. doi: 10.1139/ y05-113

Lu, J., Xing, J., and Li, J. (2012). Role for NGF in augmented sympathetic nerve response to activation of mechanically and metabolically sensitive muscle afferents in rats with femoral artery occlusion. J. Appl. Physiol. 113, 1311-1322. doi: 10.1152/japplphysiol.00617.2012

Makowska, A., Panfil, C., and Ellrich, J. (2005). Nerve growth factor injection into semispinal neck muscle evokes sustained facilitation of the jaw-opening reflex in anesthetized mice-possible implications for tension-type headache. Exp. Neurol. 191, 301-309. doi: 10.1016/j.expneurol.2004.10.001

Mansfield, K. E., Sim, J., Jordan, J. L., and Jordan, K. P. (2016). A systematic review and meta-analysis of the prevalence of chronic widespread pain in the general population. Pain 157, 55-64. doi: 10.1097/j.pain.0000000000000314

McCloskey, D. I., and Mitchell, J. H. (1972a). Reflex cardiovascular and respiratory responses originating in exercising muscle. J. Physiol. 224, 173-186. doi: 10.1113/jphysiol.1972.sp009887

McCloskey, D. I., and Mitchell, J. H. (1972b). The use of differential nerve blocking techniques to show that the cardiovascular and respirator reflexes originating in exercising muscle are not mediated by large myelinated afferents. J. Anat. $111,331-332$

McCord, J. L., Tsuchimochi, H., and Kaufman, M. P. (2009). Acid-sensing ion channels contribute to the metaboreceptor component of the exercise pressor reflex. Am. J. Physiol. Heart Circ. Physiol. 297, H443-H449. doi: 10.1152/ajpheart.00328.2009

McCord, J. L., Tsuchimochi, H., and Kaufman, M. P. (2010). P2X2/3 and $\mathrm{P}_{2} \mathrm{X}_{3}$ receptors contribute to the metaboreceptor component of the exercise pressor reflex. J. Appl. Physiol. 109, 1416-1423. doi: 10.1152/japplphysiol.00 774.2010 
McDermott, M. M. (2015). Lower extremity manifestations of peripheral artery disease: the pathophysiologic and functional implications of leg ischemia. Circ. Res. 116, 1540-1550. doi: 10.1161/CIRCRESAHA.114.303517

McDermott, M. M., Liu, K., Greenland, P., Guralnik, J. M., Criqui, M. H., Chan, C., et al. (2004). Functional decline in peripheral arterial disease: associations with the ankle brachial index and leg symptoms. JAMA 292, 453-461. doi: 10.1001/jama.292.4.453

McIver, K. L., Evans, C., Kraus, R. M., Ispas, L., Sciotti, V. M., and Hickner, R. C. (2006). NO-mediated alterations in skeletal muscle nutritive blood flow and lactate metabolism in fibromyalgia. Pain 120, 161-169. doi: 10.1016/j.pain. 2005.10.032

Mense, S. (2008). Muscle pain: mechanisms and clinical significance. Dtsch. Arztebl. Int. 105, 214-219. doi: 10.3238/artzebl.2008.0214

Mense, S. (2010). "Functional anatomy of muscle: muscle, nociceptors and afferent fibers," in Muscle Pain: Understanding the Mechanisms, eds S. Mense and R. Gerwin (Berlin, Heidelberg: Springer), 17-48.

Mense, S., and Schmidt, R. F. (1974). Activation of group IV afferent units from muscle by algesic agents. Brain Res. 72, 305-310. doi: 10.1016/00068993(74)90870-1

Mense, S., and Simons, D. G. (2001). Muscle Pain, Understanding its Nature, Diagnosis and Treatment. Philadelphia, PA: Lippincott, Williams \& Wilkins.

Meru, A. V., Mittra, S., Thyagarajan, B., and Chugh, A. (2006). Intermittent claudication: an overview. Atherosclerosis 187, 221-237. doi: 10.1016/j. atherosclerosis.2005.11.027

Messlinger, K. (1996). Functional morphology of nociceptive and other fine sensory endings (free nerve endings) in different tissues. Prog. Brain Res. 113, 273-298. doi: 10.1016/s0079-6123(08)61094-8

Mika, J., Zychowska, M., Popiolek-Barczyk, K., Rojewska, E., and Przewlocka, B. (2013). Importance of glial activation in neuropathic pain. Eur. J. Pharmacol. 716, 106-119. doi: 10.1016/j.ejphar.2013.01.072

Mizuno, M., Murphy, M. N., Mitchell, J. H., and Smith, S. A. (2011). Antagonism of the TRPv1 receptor partially corrects muscle metaboreflex overactivity in spontaneously hypertensive rats. J. Physiol. 589, 6191-6204. doi: 10.1113/jphysiol.2011.214429

Mogil, J. S., and Bailey, A. L. (2010). Sex and gender differences in pain and analgesia. Prog. Brain Res. 186, 141-157. doi: 10.1016/B978-0-444-53630-3. 00009-9

Mogil, J. S., and Belknap, J. K. (1997). Sex and genotype determine the selective activation of neurochemically-distinct mechanisms of swim stressinduced analgesia. Pharmacol. Biochem. Behav. 56, 61-66. doi: 10.1016/s00913057(96)00157-8

Mogil, J. S., Chesler, E. J., Wilson, S. G., Juraska, J. M., and Sternberg, W. F. (2000). Sex differences in thermal nociception and morphine antinociception in rodents depend on genotype. Neurosci. Biobehav. Rev. 24, 375-389. doi: 10.1016/s0149-7634(00)00015-4

Mogil, J. S., Richards, S. P., O’Toole, L. A., Helms, M. L., Mitchell, S. R., Kest, B., et al. (1997). Identification of a sex-specific quantitative trait locus mediating nonopioid stress-induced analgesia in female mice. J. Neurosci. 17, 7995-8002.

Mogil, J. S., Sorge, R. E., LaCroix-Fralish, M. L., Smith, S. B., Fortin, A., Sotocinal, S. G., et al. (2011). Pain sensitivity and vasopressin analgesia are mediated by a gene-sex-environment interaction. Nat. Neurosci. 14, 1569-1573. doi: 10.1038/nn.2941

Mogil, J. S., Sternberg, W. F., Kest, B., Marek, P., and Liebeskind, J. C. (1993). Sex differences in the antagonism of swim stress-induced analgesia: effects of gonadectomy and estrogen replacement. Pain 53, 17-25. doi: 10.1016/03043959(93)90050-y

Molliver, D. C., Immke, D. C., Fierro, L., Paré, M., Rice, F. L., and McCleskey, E. W. (2005). ASIC3, an acid-sensing ion channel, is expressed in metaboreceptive sensory neurons. Mol. Pain 1:35. doi: 10.1186/1744-8069-1-35

Molliver, D. C., Rau, K. K., McIlwrath, S. L., Jankowski, M. P., and Koerber, H. R. (2011). The ADP receptor P2Y1 is necessary for normal thermal sensitivity in cutaneous polymodal nociceptors. Mol. Pain 7:13. doi: 10.1186/1744 $-8069-7-13$

Morf, S., Amann-Vesti, B., Forster, A., Franzeck, U. K., Koppensteiner, R., Uebelhart, D., et al. (2005). Microcirculation abnormalities in patients with fibromyalgia-measured by capillary microscopy and laser fluxmetry. Arthritis Res. Ther. 7, R209-R216. doi: 10.1186/ar1459
Muir, R. L. (2009). Peripheral arterial disease: pathophysiology, risk factors, diagnosis, treatment, and prevention. J. Vasc. Nurs. 27, 26-30. doi: 10.1016/j. jvn.2009.03.001

Muller, M. D., Drew, R. C., Ross, A. J., Blaha, C. A., Cauffman, A. E., Kaufman, M. P., et al. (2015). Inhibition of cyclooxygenase attenuates the blood pressure response to plantar flexion exercise in peripheral arterial disease. Am. J. Physiol. Heart Circ. Physiol. 309, H523-H528. doi: 10.1152/ajpheart.00 267.2015

Murase, S., Kato, K., Taguchi, T., and Mizumura, K. (2014). Glial cell line-derived neurotrophic factor sensitized the mechanical response of muscular thin-fibre afferents in rats. Eur. J. Pain 18, 629-638. doi: 10.1002/j.1532-2149.2013. 00411.x

Murase, S., Terazawa, E., Hirate, K., Yamanaka, H., Kanda, H., Noguchi, K., et al. (2013). Upregulated glial cell line-derived neurotrophic factor through cyclooxygenase-2 activation in the muscle is required for mechanical hyperalgesia after exercise in rats. J. Physiol. 591, 3035-3048. doi: 10.1113/jphysiol.2012.249235

Murase, S., Terazawa, E., Queme, F., Ota, H., Matsuda, T., Hirate, K., et al. (2010). Bradykinin and nerve growth factor play pivotal roles in muscular mechanical hyperalgesia after exercise (delayed-onset muscle soreness). J. Neurosci. 30, 3752-3761. doi: 10.1523/JNEUROSCI.3803-09.2010

Murphy, M. N., Mizuno, M., Mitchell, J. H., and Smith, S. A. (2011). Cardiovascular regulation by skeletal muscle reflexes in health and disease. $\mathrm{Am}$. J. Physiol. Heart Circ. Physiol. 301, H1191-H1204. doi: 10.1152/ajpheart.002 08.2011

Nishida, Y., Saito, Y., Yokota, T., Kanda, T., and Mizusawa, H. (2009). Skeletal muscle MRI in complex regional pain syndrome. Intern. Med. 48, 209-212. doi: 10.2169/internalmedicine.48.1611

Noma, N., Shinoda, M., Honda, K., Kiyomoto, M., Dezawa, K., Nakaya, Y., et al. (2013). Interaction of IL-1 $\beta$ and $\mathrm{P}_{2} \mathrm{X}_{3}$ receptor in pathologic masseter muscle pain. J. Dent. Res. 92, 456-460. doi: 10.1177/0022034513483770

Norgren, L., Hiatt, W. R., Dormandy, J. A., Nehler, M. R., Harris, K. A., and Fowkes, F. G. (2007). Inter-society consensus for the management of peripheral arterial disease (TASC II). J. Vasc. Surg. 45, S5-S67. doi: 10.1016/j.jvs.2006. 12.037

Norris, S. L., Gober, J. R., Haywood, L. J., Halls, J., Boswell, W., Colletti, P., et al. (1993). Altered muscle metabolism shown by magnetic resonance spectroscopy in sickle cell disease with leg ulcers. Magn. Reson. Imaging 11, 119-123. doi: 10.1016/0730-725x(93)90419-e

North, R. A. (2002). Molecular physiology of P2X receptors. Physiol. Rev. 82, 1013-1067. doi: 10.1152/physrev.00015.2002

North, R. A. (2004). P2X 3 receptors and peripheral pain mechanisms. J. Physiol. 554, 301-308. doi: 10.1113/jphysiol.2003.048587

Obreja, O., Rathee, P. K., Lips, K. S., Distler, C., and Kress, M. (2002). IL-1 $\beta$ potentiates heat-activated currents in rat sensory neurons: involvement of IL-1RI, tyrosine kinase, and protein kinase C. FASEB J. 16, 1497-1503. doi: 10.1096/fj.02-0101com

Oprée, A., and Kress, M. (2000). Involvement of the proinflammatory cytokines tumor necrosis factor- $\alpha$, IL-1 $\beta$, and IL- 6 but not IL- 8 in the development of heat hyperalgesia: effects on heat-evoked calcitonin gene-related peptide release from rat skin. J. Neurosci. 20, 6289-6293.

Painter, J. T., and Crofford, L. J. (2013). Chronic opioid use in fibromyalgia syndrome: a clinical review. J. Clin. Rheumatol. 19, 72-77. doi: 10.1097/RHU. 0b013e3182863447

Paradis, S., Charles, A. L., Meyer, A., Lejay, A., Scholey, J. W., Chakfe, N., et al. (2016). Chronology of mitochondrial and cellular events during skeletal muscle ischemia-reperfusion. Am. J. Physiol. Cell Physiol. 310, C968-C982. doi: 10.1152/ajpcell.00356.2015

Peters, J. W., Schouw, R., Anand, K. J., van Dijk, M., Duivenvoorden, H. J., and Tibboel, D. (2005). Does neonatal surgery lead to increased pain sensitivity in later childhood? Pain 114, 444-454. doi: 10.1016/j.pain.2005.01.014

Pipinos, I. I., Judge, A. R., Selsby, J. T., Zhu, Z., Swanson, S. A., Nella, A. A., et al. (2008a). The myopathy of peripheral arterial occlusive disease: Part 2. Oxidative stress, neuropathy, and shift in muscle fiber type. Vasc. Endovascular Surg. 42, 101-112. doi: 10.1177/1538574408315995

Pipinos, I. I., Swanson, S. A., Zhu, Z., Nella, A. A., Weiss, D. J., Gutti, T. L., et al. (2008b). Chronically ischemic mouse skeletal muscle exhibits myopathy in association with mitochondrial dysfunction and oxidative damage. Am. 
J. Physiol. Regul. Integr. Comp. Physiol. 295, R290-R296. doi: 10.1152/ajpregu. 90374.2008

Pollak, K. A., Swenson, J. D., Vanhaitsma, T. A., Hughen, R. W., Jo, D., White, A. T., et al. (2014). Exogenously applied muscle metabolites synergistically evoke sensations of muscle fatigue and pain in human subjects. Exp. Physiol. 99, 368-380. doi: 10.1113/expphysiol.2013.075812

Posillico, C. K., Terasaki, L. S., Bilbo, S. D., and Schwarz, J. M. (2015). Examination of sex and minocycline treatment on acute morphine-induced analgesia and inflammatory gene expression along the pain pathway in Sprague-Dawley rats. Biol. Sex Differ. 6:33. doi: 10.1186/s13293-015-0049-3

Price, T. J., Louria, M. D., Candelario-Soto, D., Dussor, G. O., Jeske, N. A., Patwardhan, A. M., et al. (2005). Treatment of trigeminal ganglion neurons in vitro with NGF, GDNF or BDNF: effects on neuronal survival, neurochemical properties and TRPV1-mediated neuropeptide secretion. BMC Neurosci. 6:4. doi: 10.1186/1471-2202-6-4

Queme, L. F., Ross, J. L., Lu, P., Hudgins, R. C., and Jankowski, M. P. (2016). Dual modulation of nociception and cardiovascular reflexes during peripheral ischemia through $\mathrm{P} 2 \mathrm{Y} 1$ receptor-dependent sensitization of muscle afferents. J. Neurosci. 36, 19-30. doi: 10.1523/jneurosci.2856-15.2016

Randich, A., and Maixner, W. (1984). Interactions between cardiovascular and pain regulatory systems. Neurosci. Biobehav. Rev. 8, 343-367. doi: 10.1016/0149-7634(84)90057-5

Reinert, A., Kaske, A., and Mense, S. (1998). Inflammation-induced increase in the density of neuropeptide-immunoreactive nerve endings in rat skeletal muscle. Exp. Brain Res. 121, 174-180. doi: 10.1007/s002210050449

Riley, J. L. III., Robinson, M. E., Wise, E. A., Myers, C. D., and Fillingim, R. B. (1998). Sex differences in the perception of noxious experimental stimuli: a meta-analysis. Pain 74, 181-187. doi: 10.1016/s0304-3959(97)00199-1

Ross, J. L. (2017). Peripheral Mechanisms of Ischemic Myalgia [Dissertation]. Cincinnati, $\mathrm{OH}$ : University of Cincinnati.

Ross, J. L., Queme, L. F., Cohen, E. R., Green, K. J., Lu, P., Shank, A. T., et al. (2016). Muscle IL1 $\beta$ drives ischemic myalgia via ASIC3-mediated sensory neuron sensitization. J. Neurosci. 36, 6857-6871. doi: 10.1523/jneurosci.4582 $-15.2016$

Ross, J. L., Queme, L. F., Shank, A. T., Hudgins, R. C., and Jankowski, M. P. (2014). Sensitization of group III and IV muscle afferents in the mouse after ischemia and reperfusion injury. J. Pain 15, 1257-1270. doi: 10.1016/j.jpain.2014.09.003

Ryan, T. E., Schmidt, C. A., Green, T. D., Brown, D. A., Neufer, P. D., and McClung, J. M. (2015). Mitochondrial regulation of the muscle microenvironment in critical limb ischemia. Front. Physiol. 6:336. doi: 10.3389/fphys.2015.00336

Sadhasivam, S., Chidambaran, V., Olbrecht, V. A., Costandi, A., Clay, S., Prows, C. A., et al. (2015). Opioid-related adverse effects in children undergoing surgery: unequal burden on younger girls with higher doses of opioids. Pain Med. 16, 985-997. doi: 10.1111/pme.12660

Schmitt, P. M., and Kaufman, M. P. (2003). Estrogen attenuates the exercise pressor reflex in female cats. J. Appl. Physiol. 95, 1418-1424. doi: 10.1152 /japplphysiol.00368.2003

Scholz, J., and Woolf, C. J. (2007). The neuropathic pain triad: neurons, immune cells and glia. Nat. Neurosci. 10, 1361-1368. doi: 10.1038/nn1992

Seekamp, A., Warren, J. S., Remick, D. G., Till, G. O., and Ward, P. A. (1993). Requirements for tumor necrosis factor- $\alpha$ and interleukin-1 in limb ischemia/reperfusion injury and associated lung injury. Am. J. Pathol. 143, 453-463.

Seo, H. S., Kim, H. W., Roh, D. H., Yoon, S. Y., Kwon, Y. B., Han, H. J., et al. (2008). A new rat model for thrombus-induced ischemic pain (TIIP); development of bilateral mechanical allodynia. Pain 139, 520-532. doi: 10.1016/j.pain.2008. 06.011

Seo, H. S., Roh, D. H., Yoon, S. Y., Kang, S. Y., Moon, J. Y., Kim, H. W., et al. (2010). Peripheral acid-sensing ion channels and P2X receptors contribute to mechanical allodynia in a rodent thrombus-induced ischemic pain model. J. Pain 11, 718-727. doi: 10.1016/j.jpain.2009.10.010

Sinoway, L., Prophet, S., Gorman, I., Mosher, T., Shenberger, J., Dolecki, M., et al. (1989). Muscle acidosis during static exercise is associated with calf vasoconstriction. J. Appl. Physiol. 66, 429-436. doi: 10.1152/jappl.1989.66. 1.429

Sluka, K. A., Radhakrishnan, R., Benson, C. J., Eshcol, J. O., Price, M. P., Babinski, K., et al. (2007). ASIC3 in muscle mediates mechanical, but not heat, hyperalgesia associated with muscle inflammation. Pain 129, 102-112. doi: 10.1016/j.pain.2006.09.038

Sorge, R. E., LaCroix-Fralish, M. L., Tuttle, A. H., Sotocinal, S. G., Austin, J. S., Ritchie, J., et al. (2011). Spinal cord Toll-like receptor 4 mediates inflammatory and neuropathic hypersensitivity in male but not female mice. J. Neurosci. 31, 15450-15454. doi: 10.1523/jneurosci.3859-11.2011

Sorge, R. E., Mapplebeck, J. C. S., Rosen, S., Beggs, S., Taves, S., Alexander, J. K., et al. (2015). Different immune cells mediate mechanical pain hypersensitivity in male and female mice. Nat. Neurosci. 18, 1081-1083. doi: 10.1038/ nn. 4053

Stacey, M. J. (1969). Free nerve endings in skeletal muscle of the cat. J. Anat. 105, 231-254.

Sternbergh, W. C. III., Tuttle, T. M., Makhoul, R. G., Bear, H. D., Sobel, M., and Fowler, A. A. III. (1994). Postischemic extremities exhibit immediate release of tumor necrosis factor. J. Vasc. Surg. 20, 474-481. doi: 10.1016/07415214(94)90148-1

Stone, A. J., Copp, S. W., McCord, J. L., and Kaufman, M. P. (2015). Femoral artery ligation increases the responses of thin-fiber muscle afferents to contraction. J. Neurophysiol. 113, 3961-3966. doi: 10.1152/jn.00288.2015

Stone, A. J., and Kaufman, M. P. (2015). The exercise pressor reflex and peripheral artery disease. Auton. Neurosci. 188, 69-73. doi: 10.1016/j.autneu.2014. 10.014

Stone, A. J., Yamauchi, K., and Kaufman, M. P. (2014). Purinergic 2X receptors play a role in evoking the exercise pressor reflex in rats with peripheral artery insufficiency. Am. J. Physiol. Heart Circ. Physiol. 306, H396-H404. doi: 10.1152/ajpheart.00762.2013

Su, C. H., Chen, J. H., Lan, J. L., Wang, Y. C., Tseng, C. H., Hsu, C. Y., et al. (2015). Increased risk of coronary heart disease in patients with primary fibromyalgia and those with concomitant comorbidity-A taiwanese population-based cohort study. PLoS One 10:e0137137. doi: 10.1371/journal.pone.01 37137

Sugiyama, D., Kang, S., Arpey, N., Arunakul, P., Usachev, Y. M., and Brennan, T. J. (2017a). Hydrogen peroxide induces muscle nociception via transient receptor potential ankyrin 1 receptors. Anesthesiology 127, 695-708. doi: 10.1097/aln. 0000000000001756

Sugiyama, D., Kang, S., and Brennan, T. J. (2017b). Muscle reactive oxygen species (ROS) contribute to post-incisional guarding via the TRPA1 receptor. PLoS One 12:e0170410. doi: 10.1371/journal.pone.0170410

Svensson, P., Wang, K., Arendt-Nielsen, L., and Cairns, B. E. (2008). Effects of NGF-induced muscle sensitization on proprioception and nociception. Exp. Brain Res. 189, 1-10. doi: 10.1007/s00221-008-1399-4

Taguchi, T., Sato, J., and Mizumura, K. (2005). Augmented mechanical response of muscle thin-fiber sensory receptors recorded from rat muscle-nerve preparations in vitro after eccentric contraction. J. Neurophysiol. 94, 2822-2831. doi: $10.1152 /$ jn. 00470.2005

Taguchi, T., Yasui, M., Kubo, A., Abe, M., Kiyama, H., Yamanaka, A., et al. (2013). Nociception originating from the crural fascia in rats. Pain 154, 1103-1114. doi: 10.1016/j.pain.2013.03.017

Tariba Knežević, P., Vukman, R., Antonić, R., Kovač, Z., Uhač, I., and Simonić-Kocijan, S. (2016). The role of $\mathrm{P}_{2} \mathrm{X}_{3}$ receptors in bilateral masseter muscle allodynia in rats. Croat. Med. J. 57, 530-539. doi: 10.3325/cmj.2016. 57.530

Tsuchimochi, H., McCord, J. L., Hayes, S. G., Koba, S., and Kaufman, M. P. (2010). Chronic femoral artery occlusion augments exercise pressor reflex in decerebrated rats. Am. J. Physiol. Heart Circ. Physiol. 299, H106-H113. doi: 10.1152/ajpheart.00141.2010

Tsuchimochi, H., Yamauchi, K., McCord, J. L., and Kaufman, M. P. (2011). Blockade of acid sensing ion channels attenuates the augmented exercise pressor reflex in rats with chronic femoral artery occlusion. J. Physiol. 589, 6173-6189. doi: 10.1113/jphysiol.2011.217851

Turrini, P., Gaetano, C., Antonelli, A., Capogrossi, M. C., and Aloe, L. (2002). Nerve growth factor induces angiogenic activity in a mouse model of hindlimb ischemia. Neurosci. Lett. 323, 109-112. doi: 10.1016/s0304-3940(02) 00090-3

Villa, G., Fumagalli, M., Verderio, C., Abbracchio, M. P., and Ceruti, S. (2010). Expression and contribution of satellite glial cells purinoceptors to pain transmission in sensory ganglia: an update. Neuron Glia Biol. 6, 31-42. doi: $10.1017 / \mathrm{s} 1740925 \times 10000086$ 
Walder, R. Y., Gautam, M., Wilson, S. P., Benson, C. J., and Sluka, K. A. (2011). Selective targeting of ASIC3 using artificial miRNAs inhibits primary and secondary hyperalgesia after muscle inflammation. Pain 152, 2348-2356. doi: 10.1016/j.pain.2011.06.027

Wang, C., Song, S., Zhang, Y., Ge, Y., Fang, X., Huang, T., et al. (2015). Inhibition of the Rho/Rho kinase pathway prevents lipopolysaccharideinduced hyperalgesia and the release of TNF- $\alpha$ and IL-1 $\beta$ in the mouse spinal cord. Sci. Rep. 5:14553. doi: 10.1038/srep14553

Wang, H. J., Zucker, I. H., and Wang, W. (2012). Muscle reflex in heart failure: the role of exercise training. Front. Physiol. 3:398. doi: 10.3389/fphys.2012. 00398

Wenk, H. N., and McCleskey, E. W. (2007). A novel mouse skeletal muscle-nerve preparation and in vitro model of ischemia. J. Neurosci. Methods 159, 244-251. doi: 10.1016/j.jneumeth.2006.07.021

Wieskopf, J. S., Mathur, J., Limapichat, W., Post, M. R., Al-Qazzaz, M., Sorge, R. E., et al. (2015). The nicotinic $\alpha 6$ subunit gene determines variability in chronic pain sensitivity via cross-inhibition of $\mathrm{P} 2 \mathrm{X} 2 / 3$ receptors. Sci. Transl. Med. 7:287ra72. doi: 10.1126/scitranslmed.3009986

Wijnhoven, H. A., de Vet, H. C., and Picavet, H. S. (2006a). Explaining sex differences in chronic musculoskeletal pain in a general population. Pain 124, 158-166. doi: 10.1016/j.pain.2006.04.012

Wijnhoven, H. A., de Vet, H. C., and Picavet, H. S. (2006b). Prevalence of musculoskeletal disorders is systematically higher in women than in men. Clin. J. Pain 22, 717-724. doi: 10.1097/01.ajp.0000210912.95664.53

Wilson, B. H., and Nelson, J. (2015). Sickle cell disease pain management in adolescents: a literature review. Pain Manag. Nurs. 16, 146-151. doi: 10.1016/j. pmn.2014.05.015

Xing, J., Gao, Z., Lu, J., Sinoway, L. I., and Li, J. (2008). Femoral artery occlusion augments TRPV1-mediated sympathetic responsiveness. Am. J. Physiol. Heart Circ. Physiol. 295, H1262-H1269. doi: 10.1152/ajpheart.00 271.2008

Xing, J., Lu, J., and Li, J. (2009). Contribution of nerve growth factor to augmented TRPV1 responses of muscle sensory neurons by femoral artery occlusion. Am. J. Physiol. Heart Circ. Physiol. 296, H1380-H1387. doi: 10.1152/ajpheart.00 063.2009

Xing, J., Lu, J., and Li, J. (2012). Acid-sensing ion channel subtype 3 function and immunolabelling increases in skeletal muscle sensory neurons following femoral artery occlusion. J. Physiol. 590, 1261-1272. doi: 10.1113/jphysiol.2011. 221788
$\mathrm{Xu}$, J., and Brennan, T. J. (2009). Comparison of skin incision vs. skin plus deep tissue incision on ongoing pain and spontaneous activity in dorsal horn neurons. Pain 144, 329-339. doi: 10.1016/j.pain.2009.05.019

$\mathrm{Xu}$, J., and Brennan, T. J. (2010). Guarding pain and spontaneous activity of nociceptors after skin versus skin plus deep tissue incision. Anesthesiology 112, 153-164. doi: 10.1097/aln.0b013e3181c2952e

Yagi, J., Wenk, H. N., Naves, L. A., and McCleskey, E. W. (2006). Sustained currents through ASIC3 ion channels at the modest $\mathrm{pH}$ changes that occur during myocardial ischemia. Circ. Res. 99, 501-509. doi: 10.1161/01.res. $0000238388.79295 .4 \mathrm{c}$

Yang, K. Y., Bae, W. S., Kim, M. J., Bae, Y. C., Kim, Y. J., Kim, H. J., et al. (2013). Participation of the central p38 and ERK1/2 pathways in IL-1 $\beta$ induced sensitization of nociception in rats. Prog. Neuropsychopharmacol. Biol. Psychiatry 46, 98-104. doi: 10.1016/j.pnpbp.2013.07.004

Yawn, B. P., Buchanan, G. R., Afenyi-Annan, A. N., Ballas, S. K., Hassell, K. L., James, A. H., et al. (2014). Management of sickle cell disease: summary of the 2014 evidence-based report by expert panel members. JAMA 312, 1033-1048. doi: 10.1001/jama.2014.10517

Zamir, N., and Maixner, W. (1986). The relationship between cardiovascular and pain regulatory systems. Ann. N Y Acad. Sci. 467, 371-384. doi: 10.1111/j.17496632.1986.tb14641.x

Zemel, L., and Blier, P. R. (2016). Juvenile fibromyalgia: a primary pain, or pain processing, disorder. Semin. Pediatr. Neurol. 23, 231-241. doi: 10.1016/j.spen. 2016.10.007

Zhang, H., Li, Y., de Carvalho-Barbosa, M., Kavelaars, A., Heijnen, C. J., Albrecht, P. J., et al. (2016). Dorsal root ganglion infiltration by macrophages contributes to paclitaxel chemotherapy-induced peripheral neuropathy. J. Pain 17, 775-786. doi: 10.1016/j.jpain.2016.02.011

Conflict of Interest Statement: The authors declare that the research was conducted in the absence of any commercial or financial relationships that could be construed as a potential conflict of interest.

Copyright (c) 2017 Queme, Ross and Jankowski. This is an open-access article distributed under the terms of the Creative Commons Attribution License (CC BY). The use, distribution or reproduction in other forums is permitted, provided the original author(s) or licensor are credited and that the original publication in this journal is cited, in accordance with accepted academic practice. No use, distribution or reproduction is permitted which does not comply with these terms. 